\title{
Mısır fasulye karışık ekim sistemlerinde farklı ekim şekillerinin verim ve verim unsurları üzerine etkisi
}

\section{The effects of different sowing patterns and of corn-beans intercropping systems on yield and yield components}

\author{
Engin TAKIL $^{1} *$ iD, Nihal KAYAN ${ }^{1}$ (D), Yasin ALTAY ${ }^{2}$ iD \\ ${ }^{1}$ Eskişehir Osmangazi Üniversitesi Ziraat Fakültesi Tarla Bitkileri Bölümü, Eskişehir \\ ${ }^{2}$ Eskişehir Osmangazi Üniversitesi Ziraat Fakültesi Zootekni Bölümü, Eskişehir
}

To cite this article:

Takıl, E., Kayan, N. \& Altay, Y. (2020). Mısır fasulye karışık ekim sistemlerinde farklı ekim şekillerinin verim ve verim unsurları üzerine etkisi. Harran Tarım ve Gıda Bilimleri Dergisi, 24(1): 111-125.

DOI:10.29050/harranziraat.623989

Address for Correspondence: Engin TAKIL

e-mail:

etakil@ogu.edu.tr

Received Date:

24.09.2019

Accepted Date:

24.02.2020 öz

Araştırma 2016-2017 yıllarında Eskişehir Osmangazi Üniversitesi Ziraat Fakültesi deneme tarlalarında karışık ekim sisteminde farklı sıra üzeri mesafelerde yetiştirilen mısır ve fasulye'de bazı verim ve verim ögelerini incelemek amacıyla yürütülmüştür. Deneme tesadüf blokları deneme desenine göre üç tekerrürlü olarak kurulmuştur. Göynük-98 fasulye çeşidi ile SY Miami mısır çeşidinin materyal olarak kullanıldığı araştırmada; mısır için 20 ve $40 \mathrm{~cm}$, fasulye için ise 10 ve $20 \mathrm{~cm}$ sıra üzeri mesafeler ile yalın mısır ve fasulye yanında alternatif olarak M-F-M-F, M-F-F-M ve F-M-M-F karışık ekimleri denenmiştir. Sonuç olarak; hem mısır hem de fasulye için önemli verim ögeleri bakımından seyrek ekimler daha iyi sonuç vermiş ancak tane verimi sık ekimlerde daha yüksek olmuştur. Ekim sistemleri bakımından ise mısır ve fasulye için önemli verim ögeleri karışık ekimlerde yüksek değerler gösterirken tane verimi yalın ekimlerde daha yüksek olmuştur. Mısırda M-F-F-M, fasulyede ise F-M-M-F karışık ekim sistemleri verim ögeleri bakımından en iyi sistemler olarak belirlenmiştir.

Anahtar Kelimeler: Karışık ekim, Mısır, Fasulye, Verim, Verim ögeleri

\section{ABSTRACT}

This research was conducted at Applying Research Area, Faculty of Agriculture, University of Eskisehir Osmangazi in 2016 and 2017. The purpose of this study was to identify the effects of different sowing patterns on corn-beans intercrooping systems. The field experiment was arranged in randomized complete block design with three replications. Goynuk-98 for bean and SY Miami for corn were used as research materials. 20 and $40 \mathrm{~cm}$ row spaces for corn and 10 and $20 \mathrm{~cm}$ row spaces for bean and sole corn, sole bean, corn-bean-corn-bean, cornbean-bean-corn and bean-corn-corn-bean intercropping systems were examined in research. According to results; wide row spacings were better than narrow row spacings for important yield components both corn and beans but grain yield was higher in narrow row spacing. Intercropping systems were better than sole systems for important yield components both corn and beans but grain yield was higher in sole system. Corn-bean-beancorn for corn and bean-corn-corn-bean for bean were determines as the best intercropping systems according to yield components.

Key Words: Intercropping, Corn, Bean, yleld, Yield components.
Giriş

Dünyada ve yurdumuzda işlenebilir tarım alanlarının arttırma olanaklarının çok fazla olmaması ve hızlı nüfus artışı, tarımla uğraşanları eldeki tarım arazisinden maksimum miktarda yararlanma yollarını aramaya başlamışlardır. Bunlardan biri birlikte ekim sistemidir. Karışık 
ekim ile birim alandan daha çok ve dengeli ürün elde etmek ve yabancı otlarla rekabeti arttırmak için karışık ekim önerilmektedir (Acar ve ark., 2006).

Aynı alanda ve aynı zamanda birden fazla bitkinin birlikte yetiştirilmesi olarak tanımlanan (Ofori ve Stern, 1987) karışık ekim, sürdürülebilir tarım teknikleri içerisinde yer alan (Bauman ve ark., 2002) çeşitlendirilmiş bir tarım tekniğidir. Eş zamanlı iki bitkinin birlikte yetiştirilmesinin en belirgin üstünlüğü, toplam ürün kaybı ya da fiyat düzensizliğinden kaynaklanan riskleri önemli düzeyde azaltması ve birim alandan elde edilen toplam üründeki artışlardır (Francis, 1986).

Karışık ekimdeki amaç bitkiler arasındaki yararlı biyolojik etkileşimlerin oluşturulmasıdır. Baklagiller kullanılarak biyolojik azot fiksasyonu yoluyla toprak verimliliğini geliştirebilir ve yalın ekime göre toprağın korunumu daha iyi sağlanır. Karışık ekimde ekolojik kaynaklar daha iyi kullanılabilmekte ve yalın ekime göre çok daha üstün verim elde edilebilmektedir. Fakat karışık ekimde bitkiler tür içi ve türler arasında su, ışık ve besin maddesi bakımından bir rekabet bulunmaktadır. Bu yüzden karışık ekimden beklenen faydanın elde edilebilmesi için uygun tür, çeşit ve uygun karışımların belirlenmesi gereklidir (Lithourgidis ve ark., 2011).

Ogindo ve Walker (2005), karışık ekim sisteminin, kısa bir sürede yüksek yaprak alanı indeksine ve daha fazla yaprak alanına ulaşabildiği için toprakta suyunu büyük oranda muhafaza ettiğini bildirmişlerdir. Tsubo ve ark. (2005) Güney Afrika Cumhuriyeti'nde yaptıkları çalışmada, mısır-fasulye karışık ekiminde, mısır veriminin olumsuz yönde etkilenmediğini saptamışlardır. Çiftçi ve ark. (2006) Gevaş-Van koşullarında fasulye ve mısırın karışık ekiminde en iyi ekim düzenlemesinin koymuşlardır. Çam ve Yılmaz (2008), GürgentepeOrdu koşullarında yürüttükleri çalışmalarında mısırın fasulye ile karışık ekiminde koçanda tane sayısının, koçan veriminin artış göstermesinin fasulyenin azot katkısından olabileceğini bildirmişlerdir. Dimitrios ve ark. (2010) mısırla baklagillerin karışık ekiminin, yabancı ot yoğunluğunu tek başına ekilen mısıra göre önemli bir oranda azalttığını, bu azalmanın yabancı otların aldığı ışı̆ın azalmasından kaynaklanabileceğini belirtmektedirler.

Ülkemizde mısır baklagil birlikte yetiştiriciliği özellikle Karadeniz Bölgesinde yaygın olarak yapılmaktadır. Orta Anadolu Bölgesinde ise pek yaygın değildir. Bu amaçla Eskişehir ekolojik koşullarında karışık ekim sisteminde farklı sıra üzeri mesafelerde yetiştirilen mısır ve fasulye'de bazı verim ve verim ögeleri incelenmiştir.

\section{Materyal ve Metot}

Bu araştırma 2016-2017 yılları bitki yetiştirme döneminde, Eskişehir Osmangazi Üniversitesi Ziraat Fakültesi deneme tarlalarında yürütülmüştür. Eskişehir, Orta Anadolu Bölgesinin Batı Geçit kuşağında yer alıp, denizden yüksekliği 798 metredir. Denemenin kurulduğu bölge, $30^{\circ}$ $28^{\prime}$ Doğu boylamı ile $39^{\circ} 45^{\prime}$ Kuzey enlemlerinde bulunmaktadır. Deneme alanından toprak analizi için örnekler alınmış T.C. Tarım ve Orman Bakanlığı tarafından yetkilendirilmiş, Toprak-Su Analiz Laboratuvarında analizleri yapılmıştır. (Anonim, 2017). Toprak analizi sonuçlarına göre; deneme alanının birinci yılında toprak tınlı iken ikinci yılda killi-tınlı bünyeye sahip olmuştur. Araştırma alanları toprakları her iki yılda da nötr, organik maddesi az, tuzsuz, orta derecede fosforlu ve potasyum seviyesi yüksek, kireç yönünden zengin düzeydedir (Çizelge 1).

Çizelge 1. Deneme alanı topraklarının bazı fiziksel ve kimyasal özellikleri.

Table 1. Some physical and chemical properties of soil at the experimental area.

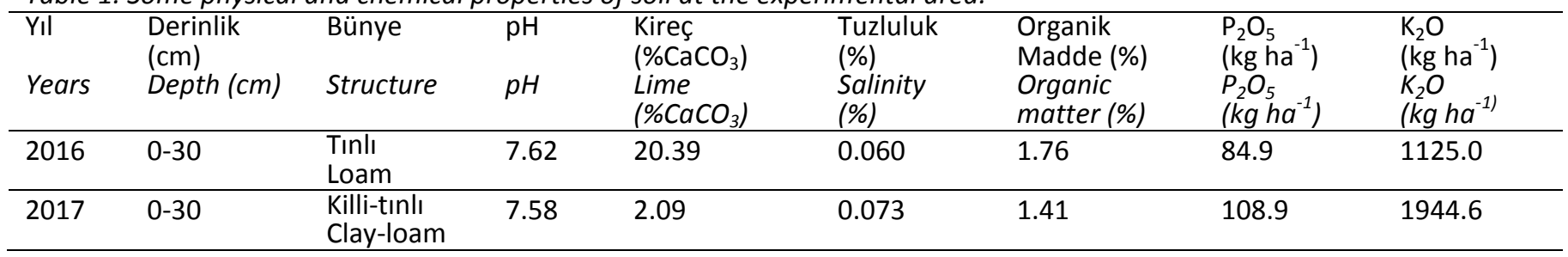


Eskişehir Meteoroloji Bölge Müdürlüğü’nden temin edilen, uzun yıllar ve araştırmanın yürütüldüğü yıllara ait iklim verileri Çizelge 2'de sunulmuştur.

Araştırmanın yürütüldüğü 2017 yılı bitki büyüme döneminde yağışın uzun yıllar ortalamasına göre yüksek olduğu, birinci yılda ise bölgenin uzun yıllar ortalamasına yakın bir yağıs alındığı görülmektedir. Aylık ortalama sıcaklık ve nispi nem değerleri ise her iki yılda da uzun yıllar ortalamasına yakın değerler göstermiştir.

Çizelge 2. Deneme alanına ait iklim verileri.

Table 2. Climatic data of the research area.

\begin{tabular}{|c|c|c|c|c|c|c|c|c|c|}
\hline \multirow{2}{*}{$\begin{array}{l}\text { Aylar } \\
\text { Months }\end{array}$} & \multicolumn{3}{|c|}{$\begin{array}{c}\text { Yağış (mm) } \\
\text { Rainfall }(\mathrm{mm})\end{array}$} & \multicolumn{3}{|c|}{$\begin{array}{c}\text { Sicaklık }\left({ }^{\circ} \mathrm{C}\right) \\
\text { Temperature }\left({ }^{\circ} \mathrm{C}\right)\end{array}$} & \multicolumn{3}{|c|}{$\begin{array}{c}\text { Nispi nem (\%) } \\
\text { Relative humudity (\%) }\end{array}$} \\
\hline & 2016 & 2017 & UY & 2016 & 2017 & UY & 2016 & 2017 & UY \\
\hline $\begin{array}{l}\text { Mayıs } \\
\text { May }\end{array}$ & 44.4 & 50.8 & 42.6 & 14.1 & 14.4 & 15.0 & 74.2 & 73.2 & 69.8 \\
\hline $\begin{array}{l}\text { Haziran } \\
\text { June }\end{array}$ & 7.0 & 44.8 & 34.7 & 21.0 & 19.1 & 19.4 & 62.1 & 73.4 & 66.9 \\
\hline $\begin{array}{l}\text { Temmuz } \\
\text { July }\end{array}$ & 12.0 & 13.4 & 5.2 & 22.8 & 23.1 & 22.4 & 58.3 & 59.5 & 62.1 \\
\hline $\begin{array}{l}\text { Ağustos } \\
\text { August }\end{array}$ & 26.4 & 31.4 & 17.7 & 22.8 & 22.0 & 22.4 & 66.0 & 67.3 & 64.1 \\
\hline $\begin{array}{l}\text { Eylül } \\
\text { September }\end{array}$ & 31.1 & 2.6 & 18.0 & 17.8 & 19.6 & 17.7 & 67.1 & 57.0 & 68.1 \\
\hline $\begin{array}{l}\text { Ort. } \\
\text { Mean }\end{array}$ & & & & 19.7 & 19.6 & 19.3 & 65.5 & 66.0 & 66.2 \\
\hline $\begin{array}{l}\text { Toplam } \\
\text { Total }\end{array}$ & 120.9 & 143.0 & 118.2 & & & & & & \\
\hline
\end{tabular}

Çizelge 3. Araştırmada uygulanan farklı ekim sistemleri

Table 3. Different sowing systems at the research

\begin{tabular}{|c|c|c|c|c|}
\hline \multirow{2}{*}{$\begin{array}{l}\text { Ekim sistemleri } \\
\text { Sowing sytems }\end{array}$} & \multicolumn{2}{|c|}{$\begin{array}{c}\text { Sıra üzeri }(\mathrm{cm}) \\
\text { Row spaces }(\mathrm{cm})\end{array}$} & \multicolumn{2}{|c|}{$\begin{array}{c}\mathrm{m}^{2} \text { de bitki sayısı (adet) } \\
\text { Number of plants per } \mathrm{m}^{2}\end{array}$} \\
\hline & $\begin{array}{l}\text { Misır } \\
\text { Corn }\end{array}$ & $\begin{array}{l}\text { Fasulye } \\
\text { Bean }\end{array}$ & $\begin{array}{l}\text { Misır } \\
\text { Corn }\end{array}$ & $\begin{array}{c}\text { Fasulye } \\
\text { Bean }\end{array}$ \\
\hline $\begin{array}{l}\text { Yalın misır } \\
\text { Sole corn }\end{array}$ & 20 & - & 7 & - \\
\hline $\begin{array}{l}\text { Yalın fasulye } \\
\text { Sole bean }\end{array}$ & - & 10 & - & 28 \\
\hline $\begin{array}{l}\text { Yalın misır } \\
\text { Sole corn }\end{array}$ & 40 & - & 4 & \\
\hline $\begin{array}{l}\text { Yalın fasulye } \\
\text { Sole bean }\end{array}$ & - & 20 & & 14 \\
\hline $\begin{array}{l}\mathrm{M}-\mathrm{F}-\mathrm{M}-\mathrm{F} \\
C-B-C-B\end{array}$ & 20 & 10 & 7 & 14 \\
\hline $\begin{array}{l}\mathrm{M}-\mathrm{F}-\mathrm{M}-\mathrm{F} \\
C-F-C-B\end{array}$ & 40 & 20 & 4 & 7 \\
\hline $\begin{array}{l}\mathrm{M}-\mathrm{F}-\mathrm{F}-\mathrm{M} \\
C-B-B-C\end{array}$ & 20 & 10 & 7 & 14 \\
\hline $\begin{array}{l}\mathrm{M}-\mathrm{F}-\mathrm{F}-\mathrm{M} \\
C-B-B-C\end{array}$ & 40 & 20 & 4 & 7 \\
\hline $\begin{array}{l}\mathrm{F}-\mathrm{M}-\mathrm{M}-\mathrm{F} \\
B-C-C-B\end{array}$ & 20 & 10 & 7 & 14 \\
\hline $\begin{array}{l}\mathrm{F}-\mathrm{M}-\mathrm{M}-\mathrm{F} \\
B-C-C-B\end{array}$ & 40 & 20 & 4 & 7 \\
\hline
\end{tabular}

Araştırmada Geçit Kuşağı Tarımsal Araştırma Enstitüsü'nden temin edilen Göynük-98 fasulye çeşidi ile Syngenta firmasından temin edilen SY Miami mısır çeşidi materyal olarak kullanılmıştır. Denemeler tesadüf blokları deneme desenine göre üç tekerrürlü olarak yürütülmüştür. Yalın ekimlerde mısır $70 \mathrm{~cm}$ sıra aralığında olacak şekilde 4 sıra halinde, fasulye ise $35 \mathrm{~cm}$ sıra arası olacak şekilde 8 sıra olarak ekilmiştir. Denemede parsel boyutları, $4 \mathrm{~m} \times 2.8 \mathrm{~m}=11.2 \mathrm{~m}^{2}$ olacak şekilde planlanmıştır. Araştırmada, yalın mısır ve fasulye ekimleri ile birlikte karışık ekim sistemleri farklı sıra üzeri mesafelerde denenmiştir. Denemede uygulanan ekim sistemleri Çizelge 3'de verilmiştir. Ekim 13 Mayıs 2016 ve 3 Mayıs 2017 tarihlerinde gerçekleştirilmiştir. Her iki yılda da ekimden önce taban gübre olarak, yalın ekilen fasulye parselleri hariç, geri kalan tüm parsellere 
$10 \mathrm{~kg} / \mathrm{da} \mathrm{N}, 10 \mathrm{~kg} / \mathrm{da} \mathrm{P}_{2} \mathrm{O}_{5}$ ve $10 \mathrm{~kg} / \mathrm{da} \mathrm{K}_{2} \mathrm{O}$ gelecek şekilde kompoze (15-15-15) gübresi verilmiştir. Yalın ekilen fasulye parsellerine ise dekara $14 \mathrm{~kg}$ olacak şekilde, DAP (Diamonyum fosfat) gübresi, ekim ile birlikte uygulanmıştır.

ìtiyaç görüldüğü zamanlarda denemeler, yağmurlama sulama yöntemiyle, sulanmış ve yabancı ot kontrolü yapılmıştır. Denemenin ilk yılında, fasulye hasadı 25 Eylül 2016 tarihinde mısır hasadı ise 20 Kasım 2016 tarihinde gerçekleştirilirken; ikinci yıl, fasulye hasadı 13 Eylül 2017 mısır hasadı ise 5 Kasım 2017 tarihinde gerçekleştirilmiştir. Parsel başlarından $50 \mathrm{~cm}$ 'lik kısımlar kenar tesiri olarak atılarak geri kalan alan hasat alanı olarak belirlenmiştir.

Mısır için hasat olgunluğu döneminde her parselden tesadüfi olarak 5 bitki seçilerek bitkide koçan sayısı belirlenmiştir. Her parselden seçilen 5 koçanda ise koçan ağırlığı, koçan uzunluğu, koçanda sıra sayısı, koçanda tane sayısı, koçanda tane ağırlığı, hektolitre ağırlığı ve bin tane ağırlığı belirlenmiştir. Hasat edilen parsellerdeki koçanlardan elde edilen taneler \% 15 tane nemine göre düzeltilerek tane verimi bulunmuştur (Wilhelm ve ark., 1985). Fasulyede ise hasat olgunluğu döneminde her parselden tesadüfi olarak 5 bitki seçilerek bitkide biyolojik verim, bitkide bakla sayısı, bitkide tane sayısı, baklada tane sayısı ve bitkide tane verimi belirlenmiştir. Seçilen 5 bitkinin baklaları arasından tesadüfi olarak seçilen 5 baklanın uzunlukları ölçülerek bakla uzunluğu saptanmıştır. Her parsel ayrı ayrı elle hasat edilerek biyolojik verim ve daha sonra harmanlanarak tane verimi tespit edilmiştir. Biyolojik verimin tane verime oranlanmasıyla hasat indeksi; tane verimi için harmanlanmış olan tanelerden 4 tekrarlamalı olarak yüzer tohum sayılıp tartılarak yüz tane ağırlığı belirlenmiştir (Akçin, 1974). Hem mısır hem de fasulye için her parselden alınan örneklerde Kjeldahl yöntemi kullanılarak azot içerikleri tespit edilmiş (Kaçar, 1972) ve analizler sonucu bulunan azot miktarı 6.25 katsayısıyla çarpılarak tanelerin içerdiği ham protein oranları hesaplanmıştır (Bremner, 1965).

Araştırmadan elde edilen sonuçlar tesadüf blokları faktöriyel deneme desenine göre varyans analizi ile değerlendirilmiş, ortalamalar Duncan testi ile karşılaştırılmıştır. Analizler için MSTAT-C paket programı kullanılmıştır.

\section{Araştırma Bulguları ve Tartışma}

Yalın mısır ve fasulye ekimleri ile birlikte karışık ekim sistemlerinin farklı sıra üzeri mesafelerde denendiği araştırmada mısır için hektolitre ağırlığı bakımından yıllar ve sıra üzeri mesafeler arasındaki farklılıklar ve yıl $x$ ekim sistemi interaksiyonu dışındaki interaksiyonlar, koçandaki sıra sayısı bakımından yıllar dışındaki etkiler istatistiki anlamda önemsiz bulunmuştur. Bunların haricinde incelenen tüm özelliklerde yıllar, sıra üzeri ve ekim sistemleri arasındaki farklılıklar önemlidir (Çizelge 4, 5).

Araştırmamızda bitkide koçan sayısı hariç incelenen tüm özelliklerde birinci yıla ait değerler, ikinci yıla oranla daha yüksek olmuştur (Çizelge 4, 5). Araştırmanın ikinci yılında mısır bitkisinin tane doldurma dönemine denk gelen Eylül ayı sıcaklıkları, birinci yıla oranla daha yüksek ancak, nispi nemi hayli düşük olmuştur (Çizelge 2). Sönmez ve Kınacı (2014) mısırda döllenme ve tane gelişim dönemlerinde yaşanan yüksek sıcaklıkların döllenmeden sonra tane dolum döneminin kısalmasına neden olduğu için koçan ağırlığının daha az olabileceğini bildirmektedirler. Benzer şekilde Moosavi (2012) yaptığı çalışmada stresin koçan çapını düşürdüğünü rapor etmiş ve söz konusu düşüşü stres altında oluşan düşük asimilat birikimine bağlamıştır. Akarken (2016) yüksek sıcaklığın tanede koçan sayısını azalttığını bildirirken, Sun ve ark. (2013) mısırda yüksek sıcaklığa bağlı olarak bin tane ağırlığının azaldığını kaydetmişlerdir. Tekkanat ve Soylu (2005) mısırda protein oranının yetiştirme tekniğine, çeşide, toprak ve iklim şartlarına göre de değiştiğini bildirmektedirler. Mısırda verim ve önemli verim ögeleri üzerine iklim koşulları ve yetiştirme teknikleri etkilidir (Kuşvuran ve Nazlı, 2014). İkinci yıl yaşanan yüksek sıcaklıklar önemli verim ögelerini olumsuz etkileyerek tane veriminin de daha düşük olmasına neden olmuş olabilir. Mısırda seyrek yapılan ekimlerde incelediğimiz tüm özellikler daha yüksek değerler gösterirken tane verimi sık ekimlerde daha yüksek olmuştur (Çizelge 4, 5). 
Takıl ve ark., 2020. Harran Tarım ve Gıda Bilimleri Dergisi, 24(1): 111-125

Çizelge 4. Farklı ekim sistemleri ve ekim şekillerinin mısırda incelenen bazı özelliklere etkisi Table 4. Effects of different sowing systems and forms on some traits of corn

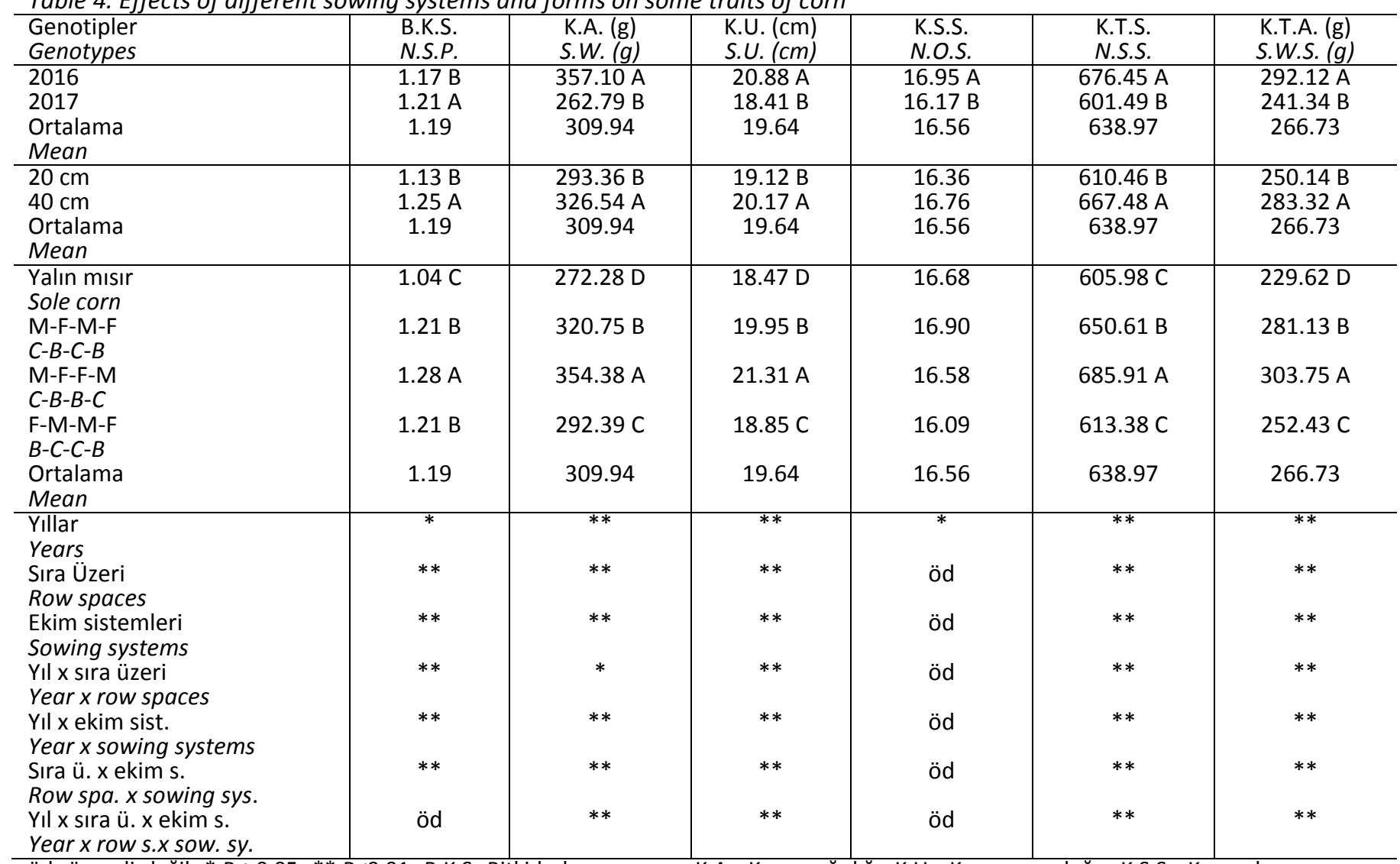

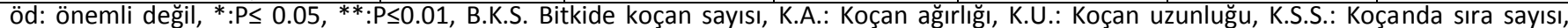

K.T.S.: Koçanda tane sayısı, K.T.A.: Koçanda tane ağırlığı, M-F-M-F: Mısır-Fasulye-Mısır-Fasulye, M-F-F-M: Mısır-Fasulye-Fasulye-Mısır, F-M-

M-F: Fasulye-Mısır-Mısır-Fasulye

N.S.P.: Number of stubs per plant, S.W.: Stub weight, S.U.: Stub lenght, N.O.S.: Number of order per stub, N.S.S.: Number of seed per stub,

S.W.S.: Seed weight per stub, C-B-C-B: Corn-Bean-Corn-Bean, C-B-B-C: Corn-Bean-Bean-Corn, B-C-C-B: Bean-Corn-Corn-Bean

Çizelge 5. Farklı ekim sistemleri ve ekim şekillerinin mısırda incelenen bazı özelliklere etkisi

Table 5. Effects of different sowing systems and forms on some traits of corn

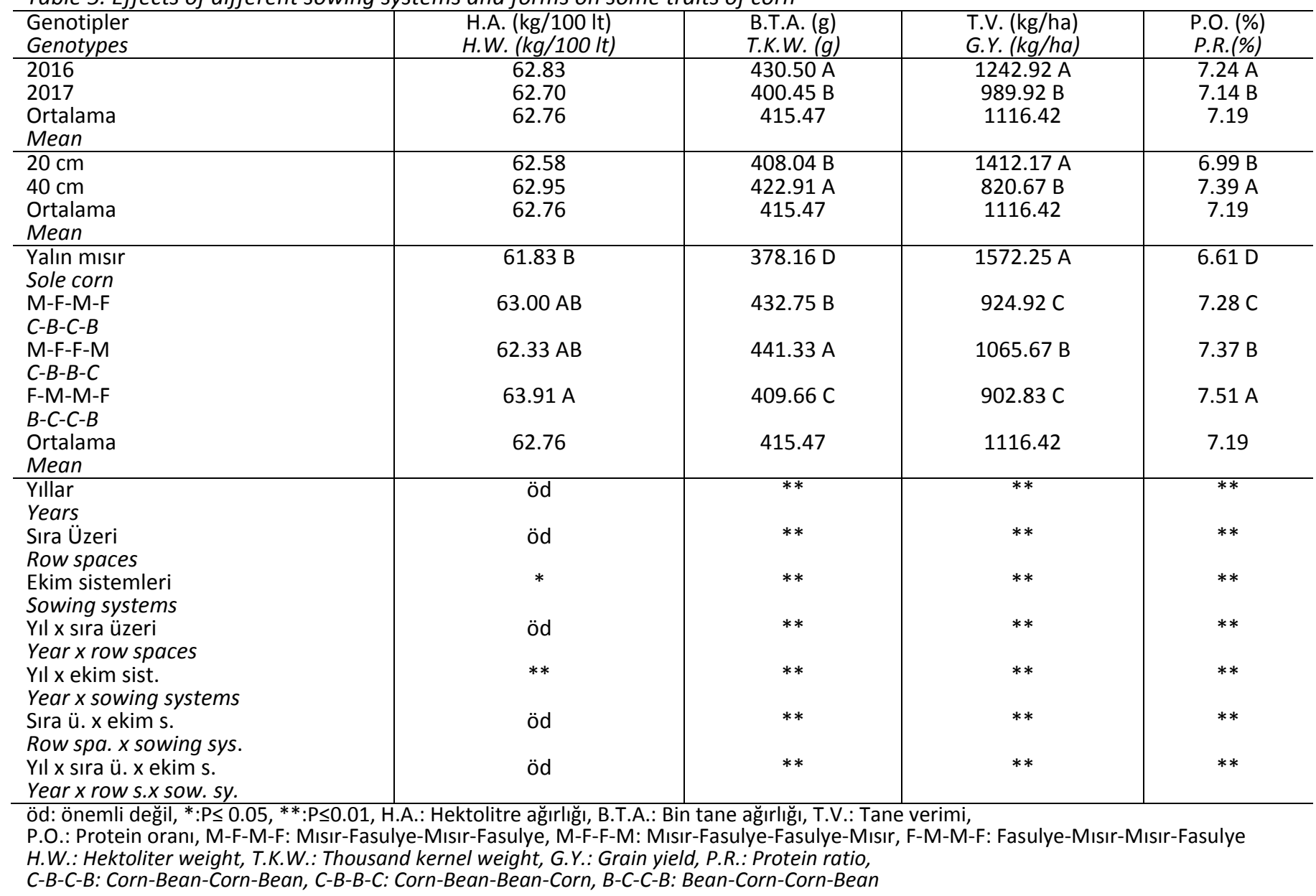


Hassan (2000), sık ekimlerde bitki başına düşen gelişme alanının azaldığını ve dolayısıyla bitkiler arasında besin elementi, ışık ve su bakımından artan rekabeti artırdığını kaydetmiştir. Bu nedenle önemli verim ögeleri seyrek ekimlerde daha yüksek çıkmış olabilir. Mısır ile yapılmış diğer çalışmalarda en yüksek koçan uzunluğu, koçanda tane sayısı, koçan ağırlığı, bitkide koçan sayısı seyrek ekimlerde elde edilmiştir (Cesurer ve ark., 1995; Turgut ve ark., 1997; Turgut, 2000; Öktem ve ark., 2001; Alıcı, 2005; Saruhan ve Şireli, 2005; Yılmaz, 2005; Kara ve Kırtok, 2006; Bhatt, 2012; Moretti, 2012).

Bizim sonuçlarımızla benzer olarak Akgün ve Burcu (2018), ekim sıklığı arttıkça mısırda protein oranının azaldığını bildirmektedirler. Araştırmamızda sık ekimlerde tane verimi daha yüksek olmuştur. Birim alanda daha fazla sayıda bitki olması, dekara koçan veriminin de daha yüksek olmasına neden olmuştur. Birim alanda net fotosentez miktarının fazla olması, daha fazla kuru madde üretilmesine neden olmuş ve dekara tane verimi sık ekimlerde daha fazla olmuştur. Mohammadi ve Alıkhanı (2007), Farhadi et al. (2009) ve Bhatt (2012) ekim sıklığı arttıkça koçan veriminin de arttığını bildirilmişlerdir.

Araştırmamızda en yüksek tane verimi yalın mısır ekimlerinden elde edilirken, hektolitre ağırlığı ve protein oranı en yüksek fasulye-mısırmısır-fasulye (F-M-M-F) karışık ekimlerinde belirlenmiştir. Geri kalan tüm önemli verim ögeleri ise mısır-fasulye-fasulye-mısır (M-F-F-M) karışık ekimlerinde en yüksek değerleri göstermiştir. Koçan ağırlığı ve uzunluğu, koçanda tane sayısı ve tane ağırlığı M-F-F-M karışık ekiminde daha yüksek çıkmıştır. Bu ekim sisteminde mısırlar birbirine uzak mesafede olduğundan bitkiler güneş ışı̆̆ından daha fazla yararlanmış ve böylelikle koçanlar daha iyi gelişme imkanı bulmuşlardır. Bu özelliklere ait en düşük değerler yalın mısır ekimlerinden elde edilmiştir. Işık yetersizliğine bağlı olarak, fotosentez ürünlerinin azalması koçana daha az karbonhidrat gelmesine neden olmuştur (Pekşen, 1998). Tiryaki (2001) karışık ekim sistemlerinde en yüksek koçan uzunluğunu saptadığını bildirirken,
Öner ve Aykutlu (2017) koçanda tane sayısı ve bin tane ağırlığını karışık ekimlerde yalın ekimlere oranla daha yüksek bulduklarını bildirmektedirler. Araştırmamızda önemli verim ögelerinin aksine tane verimi en yüksek yalın ekimlerde belirlenmiştir. Tiryaki ve ark. (2004), Geren ve ark. (2007), Öner ve Aykutlu (2017) mısırda tane veriminin yalın ekimlerde karışık ekimlere oranla daha yüksek olduğunu bildirmişlerdir. Rao ve Willey (1983) karışık ekimlerde bitkilerin kök bölgesinin birbirine olan yakınlığına bağlı olarak kök bölgesinde yaşanan türler arası rekabetin artması sonucunda karışı ekimlerde tane veriminin yalın ekimlere oranla daha düşük olabileceğini bildirmektedirler. Araştırmamızda mısırda karışık ekimler ve yalın ekimlerde $\mathrm{m}^{2 \prime}$ de bitki sayımız aynı olmasına rağmen, yalın ekimlerin tane veriminin yüksek olmasının sebebinin karışık ekimlerdeki rekabet olabileceği düşünülmektedir (Çizelge 3). Buna karşılık, Muoneke ve ark. (2007) mısırın tane veriminin karışık ekimlerde daha yüksek olduğunu bildirmektedirler. Bu durum, denemelerde kullanılan çeşitlerin ve ekim sistemlerinin farklılığından kaynaklanmış olabilir. Araştırmamızda karışık ekim sistemlerinde daha yüksek tanede protein oranı saptanmıştır. Başçiftçi (2012) mısır-fasulye karışık ekiminde mısırda protein oranının karışı ekim sistemlerinde yalın ekimlere oranla daha yüksek olduğunu, bunun nedeninin ise fasulyenin azot desteğinin olabileceğini bildirmiştir.

Bitkide koçan sayısı bakımından, $20 \mathrm{~cm}$ sıra üzeri mesafeyle ekilen bitkiler ikinci yıl yüksek değerler gösterirken, birinci yıl daha düşük değerler göstermişlerdir (Şekil 1A). Bu farklı tepkiler yıl $x$ sıra üzeri interaksiyonunun önemli çıkmasına neden olmuştur. Bitkide koçan sayısı bakımından mısır-fasulye-mısır-fasulye (M-F-M-F) karışık ekim sistemi ikinci yıl daha düşük değerler gösterirken, diğer ekim sistemlerinde ikinci yıl daha yüksek değerler göstermiştir (Şekil 1B). Hektolitre ağırlığı ise M-F-M-F karışık ekim sisteminde ikinci yılda yüksek çıkarken, diğer sistemlerde ikinci yılda daha düşük değerler göstermiştir (Şekil 4B). 


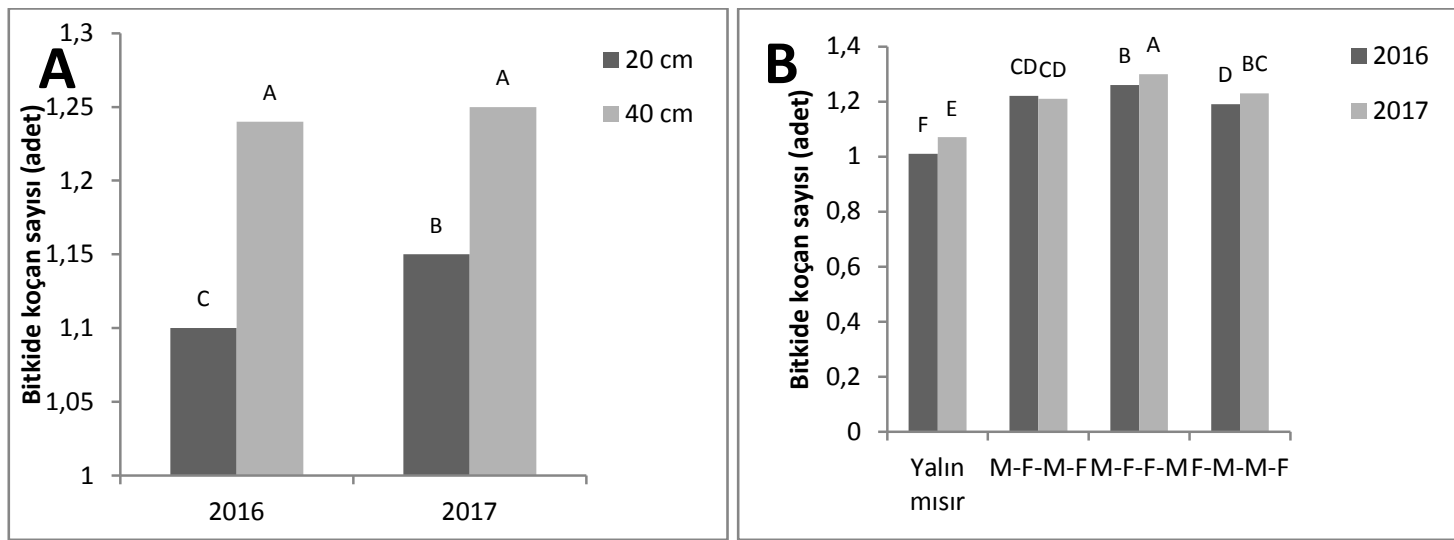

Şekil 1. Mısırda bitkide koçan sayısı (A, B) bakımından mısır-fasulye karışık ekim sistemine ait interaksiyonlar. Her çubuktaki harfler $\mathrm{P}<0.01$ 'deki önem seviyesini temsil eder

Figure 1. The interactions of corn- bean intercropping systems on number of stubs per plant $(A, B)$. Letters on each bar represent significance level at $P<0.01$

Yıl x ekim sistemleri interaksiyonlarının önemli çıkmasının nedeni bu farklı tepkiler olabilir. Bitkide koçan sayısı bakımından tüm karışık ekim sistemleri ve yalın ekimde $20 \mathrm{~cm}$ sıra üzeri mesafe ile ekilen bitkiler düşük değerler gösterirken, 40 cm sıra üzeri mesafe ile ekilen bitkiler daha yüksek değerler göstermiştir. Sıra üzeri x ekim sistemleri interaksiyonunun önemli çıkmasının nedeni bu farklı tepkiler olabilir (Şekil 2A).
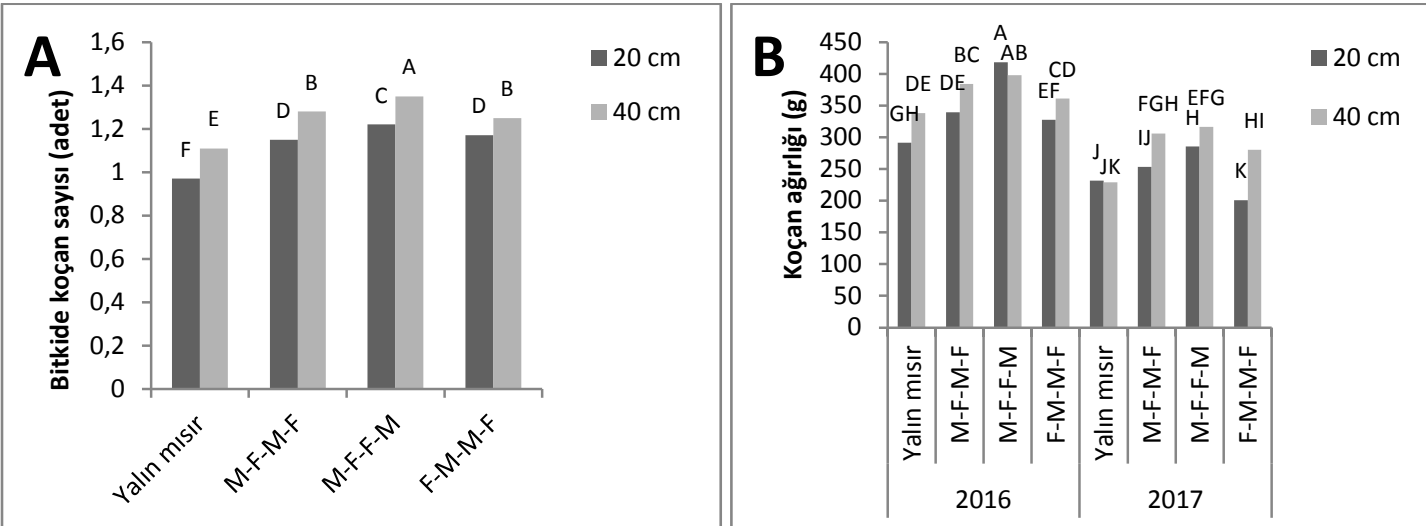

Şekil 2. Mısırda bitkide koçan sayısı (A) ve koçan ağırlığı (B) bakımından mısır-fasulye karışık ekim sistemine ait interaksiyonlar. Her çubuktaki harfler $\mathrm{P}<0.01^{\prime}$ deki önem seviyesini temsil eder.

Figure 2. The interactions of corn- bean intercropping systems on number of stubs per plant ( $A)$ and stub weight (B). Letters on each bar represent significance level at $P<0.01$

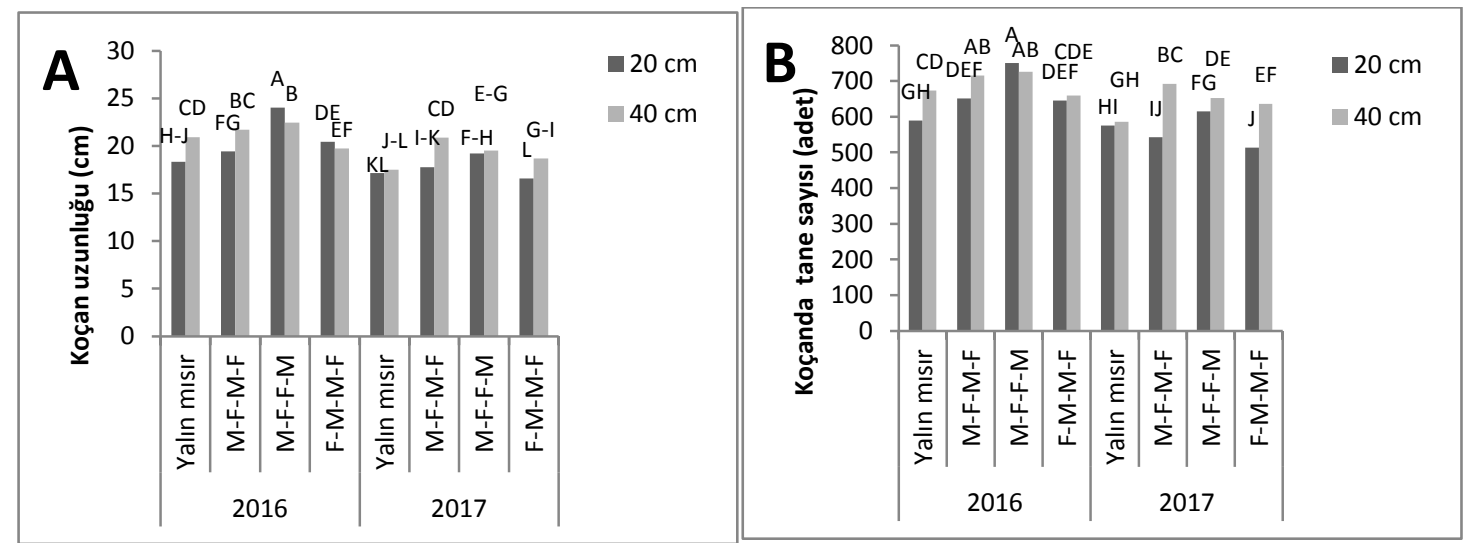

Şekil 3. Mısırda koçan uzunluğu (A) ve koçanda tane sayısı (B) bakımından mısır-fasulye karışık ekim sistemine ait interaksiyonlar. Her çubuktaki harfler $\mathrm{P}<0.01$ 'deki önem seviyesini temsil eder.

Figure 3. The interactions of corn- bean intercropping systems on stub lenght (A) and number of seeds per stub (B). Letters on each bar represent significance level at $P<0.01$

Karışık ekim sistemlerinde bazı sıra üzeri mesafelerinde koçan ağırlığı bakımından birinci yıl
M-F-F-M dışındaki seyrek ekimler daha yüksek çıkmıştır. Bu tepkilerin yıl x sıra üzeri x ekim 
sistemleri interaksiyonlarının önemli çıkmasına neden olduğu söylenebilir (Şekil 2B). Koçan uzunluğu bakımından birinci yıl M-F-F-M ve F-M$M-F$ dışındaki seyrek ekimler daha yüksek çıkmıştır. Bu tepkiler yıl $x$ sıra üzeri $x$ ekim sistemleri interaksiyonlarının önemli çıkmasına neden olmuş olabilir (Şekil 3A).
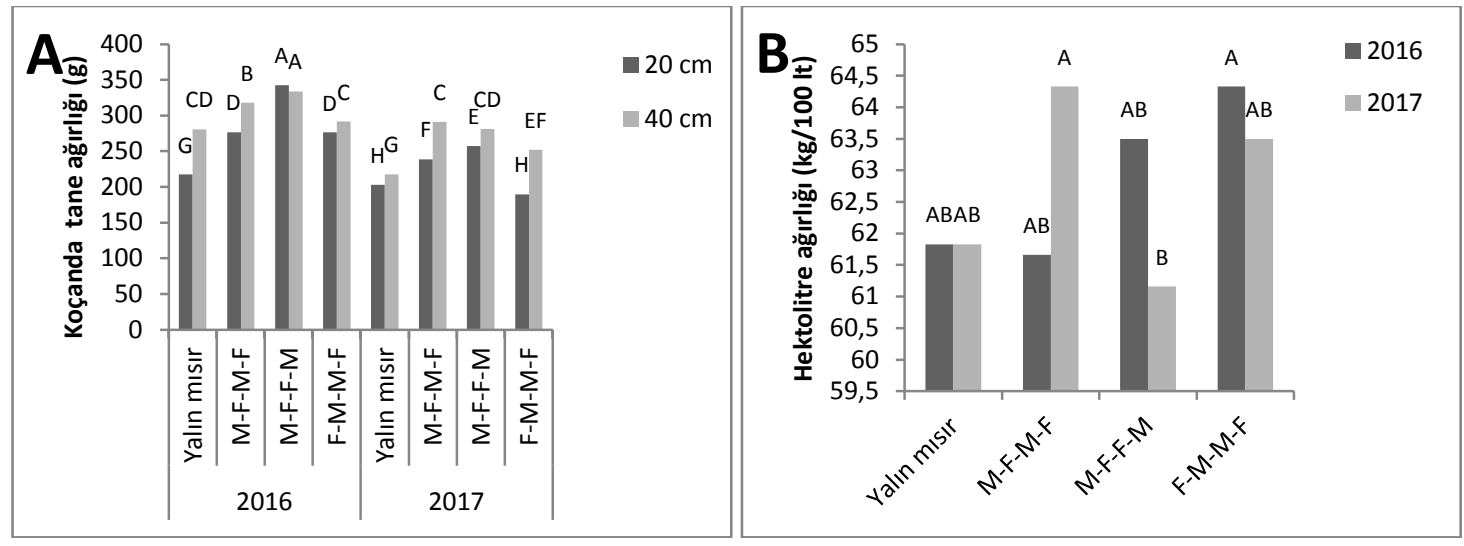

Şekil 4. Mısırda koçanda tane ağırlığı(A) ve hektolitre ağırlığı (B) bakımından mısır-fasulye karışık ekim sistemine ait interaksiyonlar. Her çubuktaki harfler $P<0.01^{\prime}$ deki önem seviyesini temsil eder.

Figure 4. The interactions of corn- bean intercropping systems on seed weight per stub (A) and hectoliter weight (B). Letters on each bar represent significance level at $P<0.01$

Bin tane ağırlığı bakımından, ikinci yıl M-F-M-F dışında seyrek ekimler daha yüksek çıkmıştır. Bu tepkiler yıl $x$ sıra üzeri $x$ ekim sistemleri interaksiyonlarının önemli çıkmasına neden olmuş olabilir (Şekil 5A). Tane verimi bakımından tüm
Koçanda tane sayısı, koçanda tane ağırlığı ve protein oranı bakımından, birinci yıl M-F-F-M dışında seyrek ekimler daha yüksek çıkmıştır.

$\mathrm{Bu}$ tepkilerin yıl $\mathrm{x}$ sıra üzeri $\mathrm{x}$ ekim sistemleri interaksiyonlarının önemli çıkmasına neden olduğu söylenebilir (Şekil 3B, 4A, 6A). yıllar ve ekim sistemlerinde sık ekimler daha yüksek değerler gösterirken seyrek ekimler daha düşük değerler göstermiştir. Bu farklı tepkiler yıl $x$ sıra üzeri $x$ ekim sistemleri interaksiyonlarının önemli çıkmasına neden olmuş olabilir (Şekil 5B).

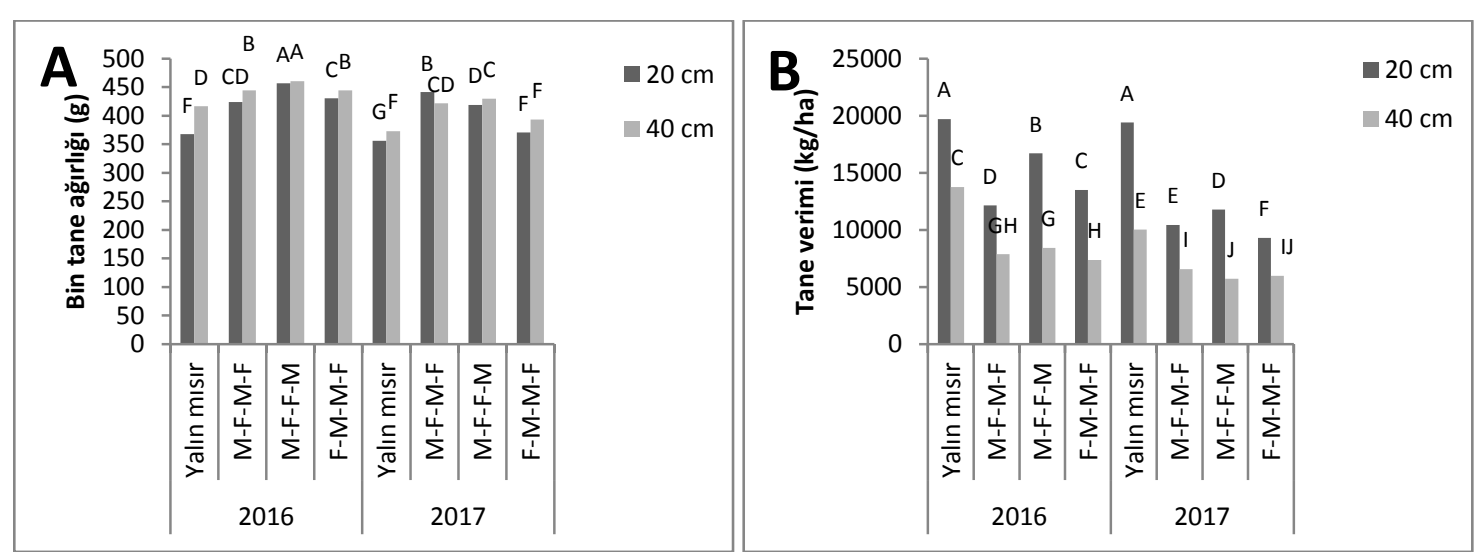

Şekil 5. Mısırda bin tane ağırlığı (A) ve tane verimi (B) bakımından mısır-fasulye karışık ekim sistemine ait interaksiyonlar. Her çubuktaki harfler $\mathrm{P}<0.01$ 'deki önem seviyesini temsil eder.

Figure 5. The interactions of corn- bean intercropping systems on thousand kernel weight (A) and grain yield (B). Letters on each bar represent significance level at $P<0.01$

Fasulye için hasat indeksi bakımından yıllar, sıra üzeri mesafeler ve ekim sistemleri arasındaki farklılıklar istatistiki anlamda önemsiz bulunurken, baklada tane sayısı bakımından yıl $x$ sıra üzeri interaksiyonu ve yıl $x$ ekim sistemleri interaksiyonu, bakla uzunluğu bakımından yıllar 


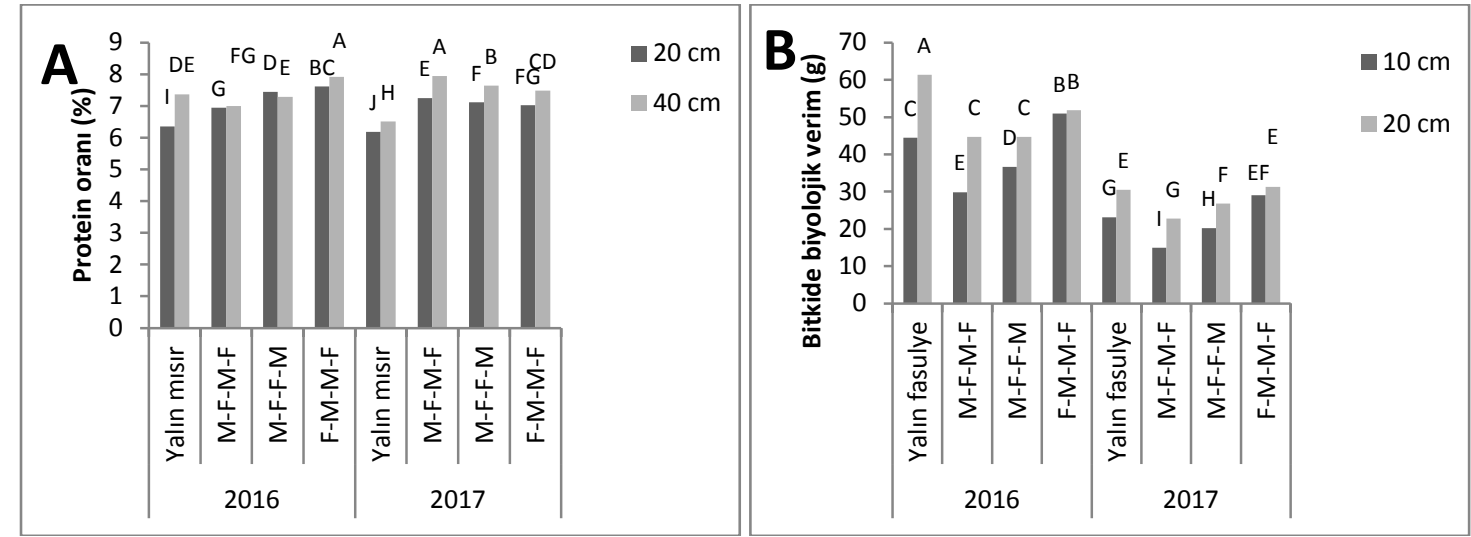

Şekil 6. Mısırda protein oranı (A) ve fasulyede bitkide biyolojik verim (B) bakımından mısır-fasulye karışık ekim sistemine ait interaksiyonlar. Her çubuktaki harfler $P<0.01$ 'deki önem seviyesini temsil eder.

Figure 6. The interactions of corn- bean intercropping systems on protein ratio of corn (A) and biological yield per plant of bean $(B)$. Letters on each bar represent significance level at $P<0.01$

Çizelge 6. Farklı ekim sistemleri ve ekim şekillerinin fasulyede incelenen bazı özelliklere etkisi

Table 6. Effects of different sowing systems and forms on some traits of bean

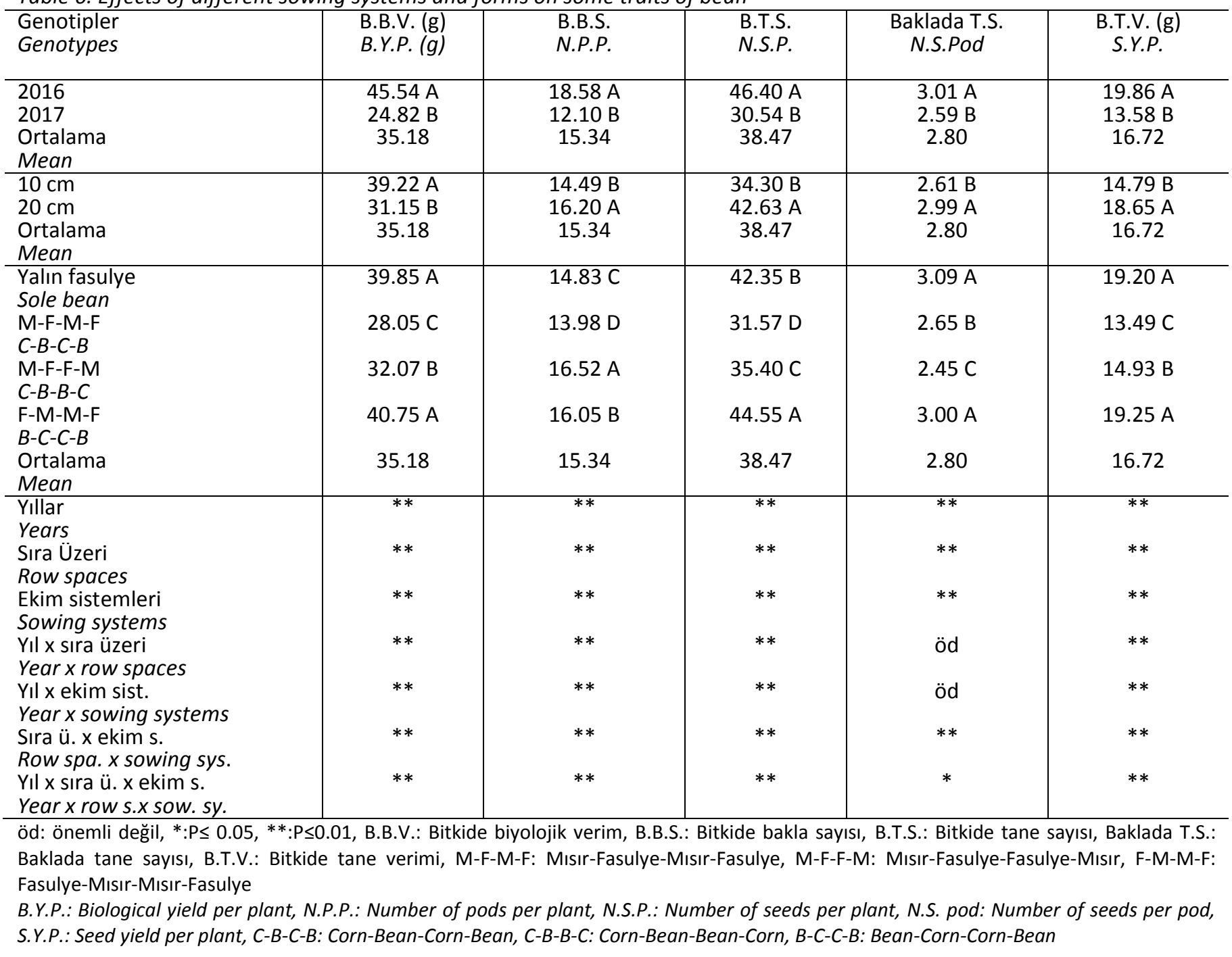

Fasulye için incelediğimiz özelliklerden yüz tane ağırlığı ve protein oranı ikinci yıl daha yüksek değerler gösterirken, diğer önemli verim ögeleri birinci yıl daha yüksek değerler göstermiştir (Çizelge 6, 7). Araştırmanın ikinci yılında vejetasyon döneminde alınan toplam yağış miktarı birinci yıla oranla yüksek olmuştur (Çizelge 2). Kaçar ve ark. (2004) kuru fasulye çeşitleri ile yürüttükleri araştırmalarının ilk yılında $51.7 \mathrm{~g}$ olarak tespit ettikleri yüz tane ağırlığının, kurak ve sıcak geçen ikinci yılda 37.3 g'a gerilediğini belirlemişlerdir. Her ne kadar fasulye sulanan bir 
bitki olsa da araştırmamızda birinci yılın daha kurak geçmesinin yüz tane ağırlığını düşürdüğü düşünülmektedir. Fasulyede incelenen önemli verim ögeleri ve tane verimi birinci yıl ikinci yıla oranla daha yüksek olmuştur. Araştırmamızın ikinci yılında bitkilerin ilk gelişme dönemleri olan Haziran ayı içerisinde sıcaklıkların birinci yıla oranla daha düşük olmuştur (Çizelge 1).

Çizelge 7. Farklı ekim sistemleri ve ekim şekillerinin fasulyede incelenen bazı özelliklere etkisi

Table 7. Effects of different sowing systems and forms on some traits of bean

\begin{tabular}{|c|c|c|c|c|c|c|}
\hline $\begin{array}{l}\text { Genotipler } \\
\text { Genotypes }\end{array}$ & $\begin{array}{l}\text { B.U. }(\mathrm{cm}) \\
\text { P.L. }(\mathrm{cm})\end{array}$ & $\begin{array}{l}\text { H.i. (\%) } \\
\text { H.I. (\%) }\end{array}$ & $\begin{array}{l}\text { Y.T.A.(g) } \\
\text { H.K.W. }(g) \\
\end{array}$ & $\begin{array}{l}\text { B.V. (kg/ha) } \\
\text { B.Y. }(\mathrm{kg} / \mathrm{ha})\end{array}$ & $\begin{array}{l}\text { T.V.(kg/ha) } \\
\text { G.Y.(kg/ha) }\end{array}$ & $\begin{array}{l}\text { P.O. (\%) } \\
\text { P.R. (\%) }\end{array}$ \\
\hline 2016 & 11.61 & 43.72 & $42.79 \mathrm{~B}$ & $3691.67 \mathrm{~A}$ & $1598.12 \mathrm{~A}$ & $24.39 \mathrm{~B}$ \\
\hline 2017 & 11.72 & 43.78 & $44.42 \mathrm{~A}$ & 2592.08 B & $1121.29 \mathrm{~B}$ & $25.55 \mathrm{~A}$ \\
\hline $\begin{array}{l}\text { Ortalama } \\
\text { Mean }\end{array}$ & 11.66 & 43.75 & 43.60 & 3141.87 & 1359.70 & 24.97 \\
\hline $10 \mathrm{~cm}$ & $11.20 \mathrm{~B}$ & 43.55 & $43.26 \mathrm{~B}$ & $3638.75 \mathrm{~A}$ & $1570.79 \mathrm{~A}$ & 24.77 B \\
\hline $20 \mathrm{~cm}$ & $12.13 \mathrm{~A}$ & 43.96 & $43.94 \mathrm{~A}$ & $2645.00 \mathrm{~B}$ & 1148.62 B & $25.18 \mathrm{~A}$ \\
\hline $\begin{array}{l}\text { Ortalama } \\
\text { Mean }\end{array}$ & 11.66 & 43.75 & 43.60 & 3141.87 & 1359.70 & 24.97 \\
\hline $\begin{array}{l}\text { Yalın fasulye } \\
\text { Sole bean }\end{array}$ & $11.82 \mathrm{~B}$ & 43.55 & $45.92 \mathrm{~A}$ & $5147.50 \mathrm{~A}$ & $2226.75 \mathrm{~A}$ & $25.99 \mathrm{~A}$ \\
\hline $\begin{array}{l}\mathrm{M}-\mathrm{F}-\mathrm{M}-\mathrm{F} \\
C-B-C-B\end{array}$ & $11.64 \mathrm{C}$ & 43.82 & $43.15 \mathrm{~B}$ & 1989.17 D & $857.83 \mathrm{D}$ & $24.47 \mathrm{C}$ \\
\hline $\begin{array}{l}\mathrm{M}-\mathrm{F}-\mathrm{F}-\mathrm{M} \\
C-B-B-C\end{array}$ & $11.03 \mathrm{D}$ & 43.95 & $42.98 \mathrm{~B}$ & $2385.00 \mathrm{C}$ & $1037.00 \mathrm{C}$ & 24.77 B \\
\hline $\begin{array}{l}\mathrm{F}-\mathrm{M}-\mathrm{M}-\mathrm{F} \\
B-C-C-B\end{array}$ & $12.18 \mathrm{~A}$ & 43.69 & $42.36 \mathrm{C}$ & $3045.83 \mathrm{~B}$ & 1317.25 B & $24.66 \mathrm{~B}$ \\
\hline $\begin{array}{l}\text { Ortalama } \\
\text { Mean }\end{array}$ & 11.66 & 43.75 & 43.60 & 3141.87 & 1359.70 & 24.97 \\
\hline $\begin{array}{l}\text { Yillar } \\
\text { Years }\end{array}$ & öd & öd & $* *$ & $* *$ & $* *$ & $* *$ \\
\hline $\begin{array}{l}\text { Sıra Üzeri } \\
\text { Row spaces }\end{array}$ & $* *$ & öd & $* *$ & $* *$ & $* *$ & $* *$ \\
\hline $\begin{array}{l}\text { Ekim sistemleri } \\
\text { Sowing systems }\end{array}$ & $* *$ & öd & $* *$ & $* *$ & $* *$ & $* *$ \\
\hline $\begin{array}{l}\text { Yıl x sıra üzeri } \\
\text { Year x row spaces }\end{array}$ & öd & öd & $*$ & $* *$ & $* *$ & $*$ \\
\hline $\begin{array}{l}\text { YIl x ekim sist. } \\
\text { Year } x \text { sowing systems }\end{array}$ & öd & öd & $* *$ & $* *$ & $* *$ & $* *$ \\
\hline $\begin{array}{l}\text { Sıra ü. x ekim s. } \\
\text { Row spa. } x \text { sowing sys. }\end{array}$ & $* *$ & öd & $*$ & $* *$ & $* *$ & $*$ \\
\hline $\begin{array}{l}\text { Yıl x sıra ü. } x \text { ekim s. } \\
\text { Year x row s.x sow. sy. }\end{array}$ & öd & öd & öd & $* *$ & $* *$ & öd \\
\hline
\end{tabular}

öd: önemli değil, *:P $0.05, * *: P \leq 0.01$, B.U.: Bakla uzunluğu, H.I.: Hasat indeksi, Y.T.A.: Yüz tane ağırlığı, B.Y.: Biyolojik verim, T.V.: Tane verimi, P.O.: Protein oranı, M-F-M-F: Mısır-Fasulye-Mısır-Fasulye, M-F-F-M: Mısır-Fasulye-Fasulye-Mısır, F-M-M-F: Fasulye-Mısır-MısırFasulye

P.L.: Pod lenght, H.I.: harvest index, H.K.W.: Hundred kernel weight, B.Y.: Biological yield, G.Y.: Grain yield, P.R.: Protein ratio, C-B-C-B: CornBean-Corn-Bean, C-B-B-C: Corn-Bean-Bean-Corn, B-C-C-B: Bean-Corn-Corn-Bean

Roberts ve Summerfield (1987), fide çıkışından sonraki bitki gelişimi ile hava sıcaklığı arasında olumlu yönde doğrusal bir ilişkinin olduğunu bildirmektedirler. Araştırmamızın ikinci yılında önemli verim ögeleri ve tane verimi bakımından daha düşük değerler elde edilmesinin sebebi olarak ilk gelişme döneminde yaşanan düşük sıcaklıkların olduğu düşünülmektedir. Fasulyede bitkide biyolojik verim, parsel biyolojik ve tane verimi $10 \mathrm{~cm}$ aralıkla ekilen

parsellerde yüksek olurken incelenen diğer özellikler $20 \mathrm{~cm}$ aralıkla ekilen parsellerde yüksek olmuştur (Çizelge 6, 7). Araştırmamızda bitkide bakla ve tane sayısı, baklada tane sayısı, bitkide tane verimi, bakla uzunluğu ve yüz tane ağırlığı gibi önemli verim ögeleri seyrek ekimlerde daha yüksek bulunmuştur. Bitki sıklığı arttıkça bitkiler ışık ve havadan daha fazla yararlanmak istediğinden rekabete girmekte, dallanmayı azaltmakta ve daha çok boyunu uzatmaktadır. Dallanması az ve cılız olan bitkilerde verim ögelerinin az olması beklenen bir durumdur 
(Toğay ve ark., 2006). Birim alanda daha az bitki olduğunda topraktaki besin maddelerinden ve güneş ışığından bitkiler daha fazla yararlanarak tanelerini daha iyi doldurmuş ve yüz tane ağırlığı seyrek ekimlerde daha yüksek çıkmış olabilir (Karakuş ve ark., 2005). Araştırmamızda biyolojik verim ve tane verimi sık ekilen bitkilerde daha yüksek olmuştur. Geniş sıra aralıklarında bitkiler arasındaki rekabet az olmakla birlikte, su, besin elementleri, ışı vb. gibi faktörlerden tam olarak yararlanılamadığı için, toplam kütle üretimi de azalmaktadır (Gökkuş ve ark., 2015). Seyrek ekimlerde tarla boş kalmakta ve birim alan verimi buna bağlı olarak önemli ölçüde düşmektedir (Karakuş ve ark., 2005). Özcan ve Özdemir (1996) fasulyede sıra üzeri mesafe az olunca tane veriminin daha yüksek olduğunu bildirmektedirler.

Fasulyede önemli verim ögeleri karışık ekimlerde en yüksek olurken, baklada tane sayısı, yüz tane ağırlığı, biyolojik verim, tane verimi ve protein oranı yalın ekimlerde en yüksek değeri göstermiştir (Çizelge 6, 7). Pekşen ve ark. (1999) karışımdaki bitkilerin tekli sıralar yerine ikişerli veya çoklu sıralar halinde ekilmesinin baklagil bitkilerine daha fazla ışı̆ıı gelmesini sağlayabileceğini bildirmişlerdir. Bizim araştırmamızda da F-M-M-F karışık ekim sisteminde mısııın ışık, besin, su bakımından baklagillere olan rekabetinin daha az olması önemli verim ögelerinin bu düzenlemede daha yüksek çıkmış olmasına neden olmuştur. Tiryaki ve ark. (2004) bitkide bakla sayısının, Başçiftçi (2012) ise bitkide biyolojik verim, bitkide bakla sayısı ve baklada tane sayısının karışık ekimlerde daha yüksek olduğunu kaydetmişlerdir. Tansı (1987) en yüksek bin tane ağırlıklarının saf baklagil ekimlerinden elde edildiğini, baklagil sıralarının arasına giren mısırın rekabetinden (gölge etki, vb) dolayı bin tane ağırlığının olumsuz yönde etkilediğini belirtmişlerdir. Mmbaga (1983) ise bazı karışık ekim kombinasyonlarında mısır tanesinin ham protein oranı, kapama ekime göre azaldığını bildirmektedir. Benzer şekilde bizim çalışmamızda da yüz tane ağırlığı ve tanede protein oranı yalın ekimlerde daha yüksektir.
Tansı (1987) karışık ekimlerde mısırın fasulyeye gelen ışığı engellediğini, mısırın baklagillere oranla rekabet gücünün daha yüksek olmasından dolayı yalın ekimlerde tane veriminin daha yüksek çıktığını ve azalan ışığın birlikte üretimde en kritik faktör olduğunu bildirmektedir. Özellikle su ve besin maddesi rekabeti tane verimindeki düşüşün

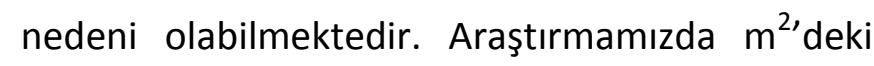
bitki sayısı yalın ekimlerde, karışık ekimlere oranla yaklaşık iki kattır. Birim alandaki bitki sayısının fazlalığı da yalın ekimlerde tane veriminin yüksek çıkmasına neden olmuş olabilir (Çizelge 3).

Fasulyede yüz tane ağırlığı ve protein oranı her iki sıra üzeri mesafeyle ekilen bitkilerde ikinci yıl yüksek değerler gösterirken birinci yıl daha düşük değerler göstermişlerdir (Şekil 9B, 12A). Bu farklı tepkiler yıl $x$ sıra üzeri interaksiyonunun önemli çıkmasına neden olmuştur. Bakla uzunluğu, yüz tane ağırlığı ve protein oranı tüm karışık ekim sistemlerinde $20 \mathrm{~cm}$ sıra üzeri mesafe ile ekilen bitkilerde yüksek değerler gösterirken, $10 \mathrm{~cm}$ sıra üzeri ile ekilen bitkilerde daha düşük değerler göstermiştir ( Şekil 9A, 10B, 13). Sıra üzeri x ekim sitemleri interaksiyonlarının önemli çıkmasının nedeni bu farklı tepkiler olabilir. Yüz tane ağırlığı ve protein oranı tüm ekim sistemlerinde ikinci yıl yüksek değerler gösterirken, birinci yıl daha düşük değerler göstermiştir (10A, 12B). Bu nedenle yıl x ekim sistemleri interaksiyonları önemli çıkmış olabilir. Bitkide biyolojik verim, bitkide tane sayısı ve bitkide tane verimi bakımından sık ekimler daha düşük değerler gösterirken, seyrek ekimler daha yüksek değerler göstermiştir (Şekil 6B, 7B, $8 B)$. Bu nedenle yıl $x$ sıra üzeri $x$ ekim sistemleri interaksiyonları önemli çıkmış olabilir. Bitkide bakla sayısı bakımından tüm sistemlerde seyrek ekimlerde daha yüksek değerler elde edilirken, FM-M-F sisteminde her iki yılda da sık ekimlerde yüksek değerler elde edilmiştir (Şekil 7A).

$\mathrm{Bu}$ durumun interaksiyonun önemli çıkmasına neden olduğu söylenebilir. Baklada tane sayısı bakımından tüm sistemlerde seyrek ekimlerde daha yüksek değerler elde edilirken, M-F-F-M sisteminde birinci yılda seyrek ekimlerde düşük değerler elde edilmiştir (Şekil 8A). Bu durumun interaksiyonun önemli çıkmasına neden olduğu 
söylenebilir. Biyolojik verim ve tane verimi bakımından sık ekimler daha yüksek değerler gösterirken, seyrek ekimler daha düşük değerler göstermiştir (Şekil 11AB). Bu nedenle yıl x sıra üzeri $x$ ekim sistemleri interaksiyonları önemli çıkmış olabilir.

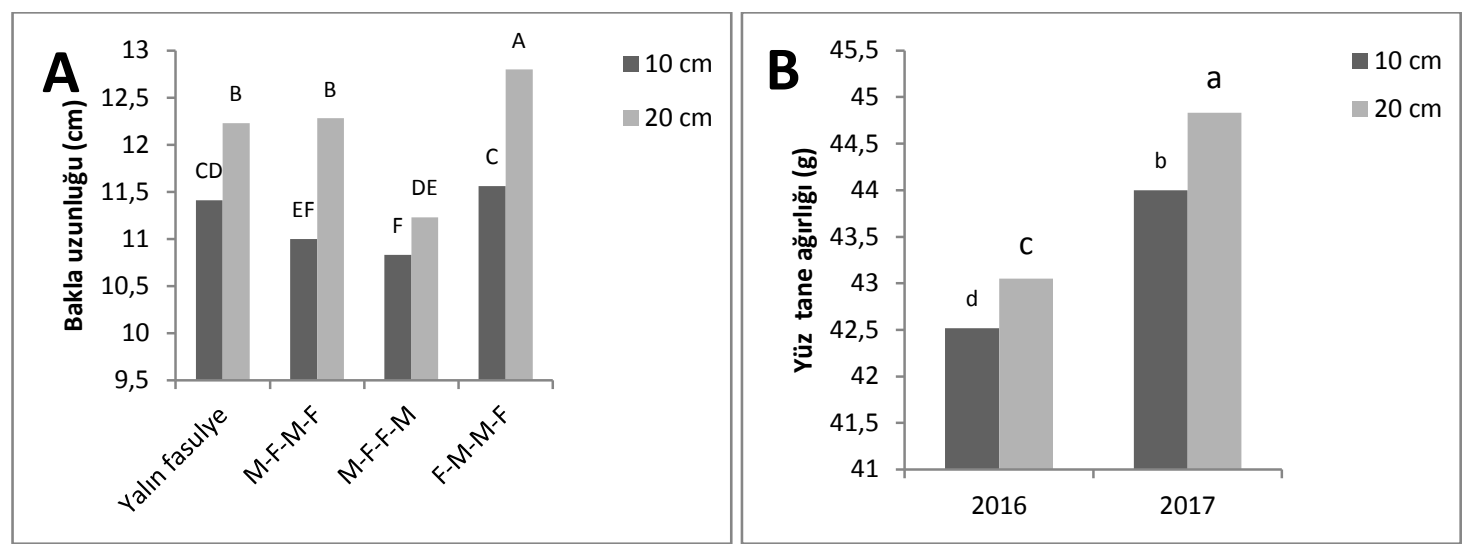

Şekil 9. Fasulyede bakla uzunluğu (A) ve yüz tane ağıllı̆ı (B) bakımından mısır-fasulye karışık ekim sistemine ait interaksiyonlar. Her çubuktaki harfler $\mathrm{P}<0.05$ ve $\mathrm{P}<0.01$ 'deki önem seviyesini temsil eder

Figure 9. The interactions of corn- bean intercropping systems on pods lenght (A) hundred kernel weight (B). Letters on each bar represent significance level at $P<0.05$ and $P<0.01$

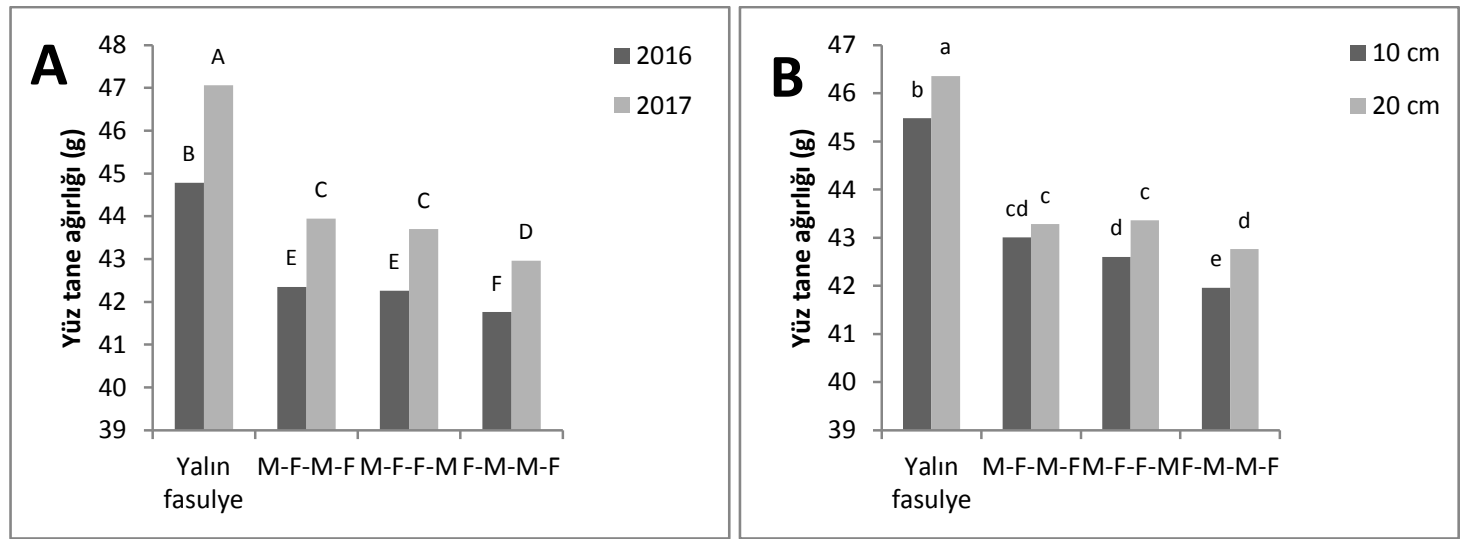

Şekil 10. Fasulyede yüz tane ağırlığı (A, B) bakımından mısır-fasulye karışık ekim sistemine ait interaksiyonlar. Her çubuktaki harfler $\mathrm{P}<0.05$ ve $\mathrm{P}<0.01$ 'deki önem seviyesini temsil eder

Figure 10. The interactions of corn- bean intercropping systems on hundred kernel weight $(A, B)$. Letters on each bar represent significance level at $P<0.05$ and $P<0.01$

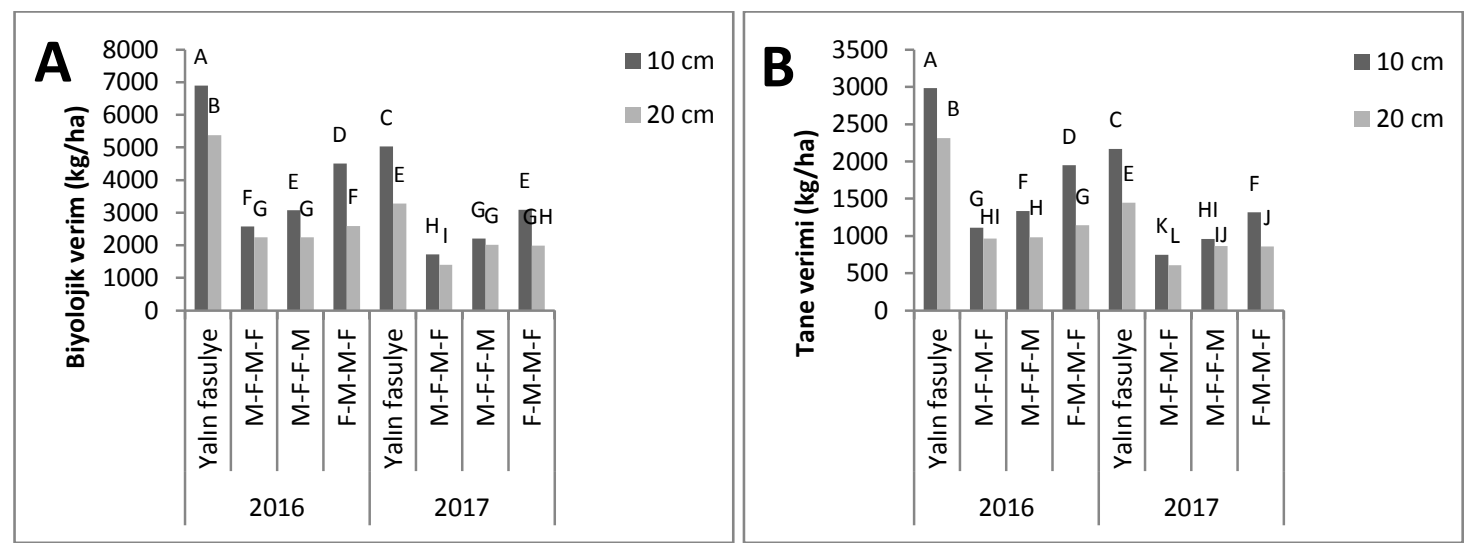

Şekil 11. Fasulyede biyolojik verim (A) ve tane verimi (B) bakımından mısır-fasulye karışık ekim sistemine ait interaksiyonlar. Her çubuktaki harfler $\mathrm{P}<0.01^{\prime}$ deki önem seviyesini temsil eder

Figure 11. The interactions of corn- bean intercropping systems on biological yield (A) and grain yield (B). Letters on each bar represent significance level at $P<0.01$ 


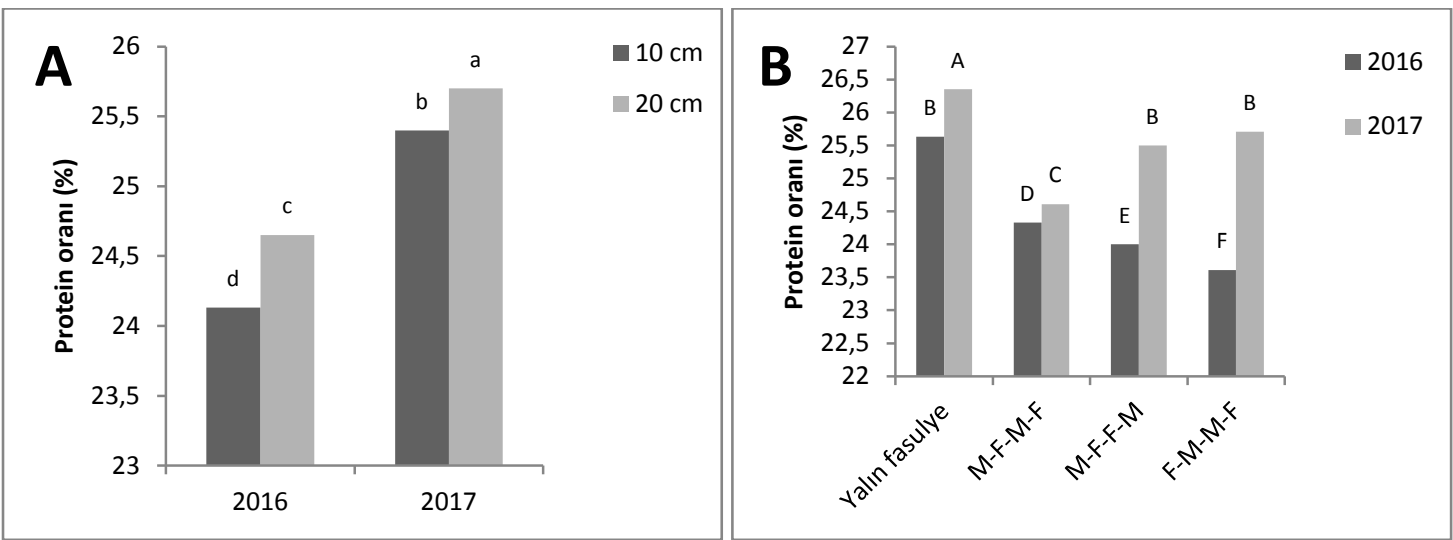

Şekil 12. Fasulyede protein oranı (A, B) bakımından mısır-fasulye karışık ekim sistemine ait interaksiyonlar. Her çubuktaki harfler $P<0.05$ ve $P<0.01$ 'deki önem seviyesini temsil eder

Figure 12. The interactions of corn- bean intercropping systems on protein ratio $(A, B)$. Letters on each bar represent significance level at $P<0.05$ and $P<0.01$

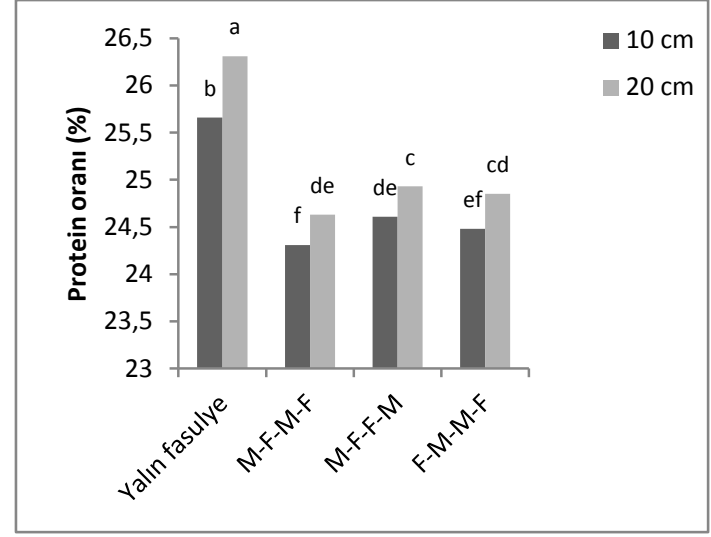

Şekil 13. Fasulyede protein oranı bakımından mısır-fasulye karışık ekim sistemine ait interaksiyonlar. Her çubuktaki harfler $\mathrm{P}$ $<0.05$ 'deki önem seviyesini temsil eder

Figure 13. The interactions of corn- bean intercropping systems onprotein ratio. Letters on each bar represent significance level at $P<0.05$

Çizelge 8. Farklı ekim sistemleri ve ekim şekillerine ait alan eşdeğer oranı (LER) değerleri

Table 8. Effects of different sowing systems and forms on LER

\begin{tabular}{|c|c|c|}
\hline $\begin{array}{l}\text { Sıra üzeri } \\
\text { Row spaces }\end{array}$ & $\begin{array}{c}\text { Ekim sistemi } \\
\text { Sowing systems }\end{array}$ & LER \\
\hline \multirow{6}{*}{$20-10 \mathrm{~cm}$} & $M-F-M-F$ & 0.93 \\
\hline & $C-B-C-B$ & \\
\hline & M-F-F-M & 1.16 \\
\hline & $C-B-B-C$ & \\
\hline & $\mathrm{F}-\mathrm{M}-\mathrm{M}-\mathrm{F}$ & 1.21 \\
\hline & $B-C-C-B$ & \\
\hline \multirow{6}{*}{$40-20 \mathrm{~cm}$} & $M-F-M-F$ & 1.01 \\
\hline & $C-B-C-B$ & \\
\hline & M-F-F-M & 1.08 \\
\hline & $C-B-B-C$ & \\
\hline & $\mathrm{F}-\mathrm{M}-\mathrm{M}-\mathrm{F}$ & 1.09 \\
\hline & $B-C-C-B$ & \\
\hline
\end{tabular}

M-F-M-F: Mısır-Fasulye-Mısır-Fasulye, M-F-F-M: MısırFasulye-Fasulye-Mısır, F-M-M-F: Fasulye-Mısır-Mısır-Fasulye $C-B-C-B$ : Corn-Bean-Corn-Bean, C-B-B-C: Corn-Bean-BeanCorn, B-C-C-B: Bean-Corn-Corn-Bean
Araştırmamızda en yüksek alan eşdeğer oranı (LER) 1.21 ile sıra üzerinin dar tutulduğu sık ekimlerde F-M-M-F karışık ekimlerinden elde edilirken en düşük LER değeri 0.93 ile yine sık ekimlerde $\mathrm{M}-\mathrm{F}-\mathrm{M}-\mathrm{F}$ ekimlerinden elde edilmiştir. (Çizelge 8). Buna göre LER değerinin yüksek bulunduğu sık ekilen F-M-M-F karışık ekim yönteminin diğer ekim yöntemlerine göre birim alan verimliliği bakımından daha avantajı olduğunu söylemek mümkündür. Sıra üzerinin dar tutulduğu M-F-M-F ekimleri ise yalın ekimlere oranla daha az avantajlı olmuştur. Tiryaki ve ark. (2004) ve Geren ve ark. (2007) karışık ekim sistemleri ile yaptıkları çalışmalarında alan kullanım etkinliğinin bir göstergesi olan LER değerlerinin farklı olabildiğini bildirmişlerdir.

\section{Sonuçlar}

Hem mısır hem de fasulye için önemli verim ögeleri bakımından seyrek ekimler daha iyi sonuç vermiş ancak, tane verimi sık ekimlerde daha yüksek olmuştur. Seyrek ekimlerde bitki başına düşen alan daha fazla olduğundan, bitkiler daha iyi gelişebilmekte bitki olduğu için daha fazla fotosentetik alan ancak, sık ekimlerde birim alanda daha fazla oluşmakta ve bunun sonunda birim alana verim daha yüksek olmaktadır. Hem mısır hem de fasulye için önemli verim ögeleri karışık ekimlerde yüksek değerler gösterirken, tane verimi yalın ekimlerde daha yüksek olmuştur. Mısırda M-F-F-M, fasulyede ise F-M-M$F$ karışık ekim sistemleri verim ögeleri bakımından en iyi sistemler olarak belirlenmiştir. LER değeri de dikkate alındığında Eskişehir ve benzer 
ekolojilerde F-M-M-F karışık ekimi ve sık ekim şeklinin önerilmesi uygundur. Karışık ekimin önerilmesinin nedeni olarak karışık ekim sistemlerinde ışık, besin, su bakımından rekabetin bitkiler için daha uygun olması düşünülebilir. Yalın ekimlerde daha yüksek tane verimi elde edilmesinin nedeni olarak ise kök bölgesinde yaşanan rekabetin olabileceği düşünülmektedir.

\section{Kaynaklar}

Acar, Z., Aşçı, Ö.Ö., Ayan, İ., Mut, H., ve Başaran, U. (2006). Yem bitkilerinde karışı ekim sistemleri. Ondokuzmayıs Üniversitesi Ziraat Fakültesi Dergisi, 21(3), 379-386.

Akarken, N. (2016). Bazı mısır genotiplerinin yüksek sıcaklığa tolerans faktörleri bakımından karşılaştırılması. Namık Kemal Üniversitesi Fen Bilimleri Enstitüsü Tarla Bitkileri Ana Bilim Dalı, Yüksek Lisans Tezi, Tekirdağ.

Alıcı, S. (2005). Kahramanmaraş koşullarında farklı azot dozları ile sıra üzeri ekim mesafelerinin II. ürün mısır (Zea mays L.) bitkisinde verim, verim unsurları ve bazı tarımsal karakterlere etkisi üzerine bir araştırma. Çukurova Üniversitesi Fen Bilimleri Enstitüsü Tarla Bitkileri Ana Bilim Dalı, Doktora Tezi, Adana.

Bauman, D. T., Bastiaans, L., Goudriaan J., Vanlaar H.H., ve Kropft, M.J. (2002). Analysing crop yield and plant quality in a intercropping system using an eco physiological model for interplant competition. Agricultural system, 73, 173-203.

Başçiftçi, Z. B. (2012). Şeker mısır ve bodur fasulyenin karışık ekiminde ekim düzenlemeleri ve bazı agronomik özelliklerin belirlenmesi. Eskişehir Osmangazi Üniversitesi Fen Bilimleri Enstitüsü Tarla Bitkileri Ana Bilim Dalı, Doktora tezi, Eskişehir.

Bhatt, P. S. (2012). Response of sweet corn hybrid to varying plant densities and nitrogen levels. African Journal of Agricultural Research, 7(46), 6158- 6166.

Bremner, V.M. (1965). Total nitrogen. Agronomy, 9, 11491178.

Burcu, Y., ve Akgün, İ. (2018). Isparta koşullarında farklı ekim zamanı ve bitki sıklığının şeker mısırında (Zea mays saccharata Sturt.) taze koçan verimi ve kalite özellikleri üzerine etkisi. Süleyman Demirel Üniversitesi Fen Bilimleri Enstitüsü Dergisi, 22(2), 679-684.

Cesurer, L. (1995). Kahramanmaraş koşullarında ekim zamanı ve ekim sıklığının şeker mısırında taze koçan verimine ve diğer bazı tarımsal ve bitkisel özelliklere etkisi. Çukurova Üniversitesi Fen Bilimleri Enstitüsü Tarla Bitkileri Ana Bilim Dalı, Doktora Tezi, Adana.

Çam, E., ve Yılmaz, G. (2008). Ordu Gürgentepe koşullarında patates-mısır-fasulye karışık ekim sistemleri üzerinde bir araştırma. Tarım Bilimleri Araştırma Dergisi, 1(1), 1-9.

Çiftçi, V., Toğay, N., Toğay, Y., ve Doğan, Y. (2006). The Effects of intercropping sowing systems with dry bean and maize on yield and some yield components. Journal of Agronomy, 5(1), 53-56.

Dimitrios, B., Panayiota, P., Aristidis, K., Sotiria, P., Anestis, K., ve Aspasia, E. (2010). Weed-suppresive effects of maize-legume intercropping in organic farming. International Journal of Pest Management, 56, 173181.

Farhadi, A. H. R., Madani, H., Shirzadi, M.H., ve Najafi, I. (2009). Study of effects of cultivar, weed sand plant density on yield and yield components of sweet corn. Under Iranian Warm Environment Plant Ecophysiology, 1(3), 103-108.

Francis, C. A. (1986). Multiple Cropping Systems. Mac Millan Publishing Company, 866 Third Avancue, New York, NY 10022.

Geren, H., Avcıoğlu, R., Soya, H., ve Kır, B. (2007). İkinci ürün koşullarında mısır (Zea mays L.)’ın börülce (Vigna unguiculata L.) ve fasulye (Phaseolus vulgaris L.) ile birlikte ekiminin tane verimi ve bazı verim özelliklerine etkisi. Ege Üniversitesi Ziraat Fakültesi Dergisi, 44(3),27-41.

Gökkuş, A., Kantar, F., Karadoğan, T., ve Koç, A. (2015). Tarla Bitkileri (üçüncü baskı). Erzurum: Atatürk Üniversitesi Ziraat Fakültesi Yayınları.

Hassan, A. (2000). Effect of plant population density on yield and yield components of eight Egyptian maize hybrids. Field Crop Abstracts, 53, No: 5

Kaçar, B. (1972). Bitki ve Toprağın Analizleri. Il. Bitki Analizleri. Ankara Üniversitesi Ziraat Fakültesi Yayınları 453.

Kaçar, O., Çakmak, F., Çöplü, N., ve Azkan, N. (2004). Bursa koşullarında bazı kuru fasulye çeşitlerinde (Phaseolus vulgaris L.) bakteri aşılama ve değişik azot dozlarının verim ve verim unsurları üzerine etkisinin belirlenmesi. Uludağ Üniversitesi Ziraat Fakültesi Dergisi, 18(1), 207-218.

Kara, B., ve Kırtok, Y. (2006). Çukurova koşullarında değişik bitki sıklıkları ve farklı azot dozlarında mısırın tane verimi ile azot alım ve kullanım etkinliğinin belirlenmesi. Çukurova Üniversitesi Ziraat Fakültesi Dergisi, 21(2), 23-32.

Karakuş, M., Çiftçi, V., Toğay, Y., ve Toğay, N. (2005). VanGevaş koşullarında farklı sıra aralıklarının fasulye (Phaseolus vulgaris L.) de verim ve bazı verim öğelerine etkisi. Yüzüncü Yıl Üniversitesi Ziraat Fakültesi Tarım Bilimleri Dergisi, 15(1), 57-62.

Kuşvuran, A., ve Nazlı, R.i. (2014). Orta kızılırmak havzası ekolojik koşullarında bazı mısır (Zea mays L.) çeşitlerinin tane mısır özelliklerinin belirlenmesi. Yüzüncü Yıl Üniversitesi Tarım Bilimleri Dergisi, 24(3), 233- 240.

Lithourgidis, A.S., Dordas, C.A., Damalas, C.A., ve Vlachostergios, D.N. (2011). Annual intercrops: an alternative pathway for sustainable agriculture. Australian Journal of Crop Science, 5(4), 396-410.

Mmbaga, M.E.T. (1983). Effect of Associated Culture on Grain Yield, Percent Protein and Percent Oil. Maize in Association with Dry Beans, More Food from Beter Technology. (Ed. By J.C. Holmes and W.M. Tahir), 813-817, Rome, CAB Abst. 1984-86.

Mohammadi, K. H., ve Alikhani, A. M. (2007). Effect of plant density and sowing date on yield and quality of forage sweet corn. Journal of Agricultural Science, $17(2), 117-126$. 
Moosavi, S.G. (2012). The effect of water deficit stress and nitrogen fertilizer levels on morphology traits, yield and leaf area index in maize. Pakistan Journal of Botany, 44(4), 1351-1355.

Moretti, N. N. M. (2012). Responce of yield and quality to plant density and nitrogen fertilizer levels in sweet corn. California State University Master thesis, Fresno.

Muoneke, C.O., Ogwuche,M.A.O., ve Kalu, B.A. (2007). Effect of maize planting density on the performance of maize/soybean intercropping system in a guinea savannah agroecosystem. African Journal of Agricultural Research, 2(12), 667-677.

Ofori, F., ve Stern, W. R. (1987). Cereal - legume intercropping systems. Advances in Agronomy, 41, 41-90.

Ogindo, H.E., ve Walker, S. (2005). Comparison of measured changes in seasonal soil water content by rained maize-bean intercrop and component cropping in semiarid region in Southern Africa. Physics and Chemistry of the Earth, 30(11), 799-808.

Öktem, A., Ülger, A. C., ve Kırtok, Y. (2001). The effect of different doses and intrarows spaces on grain yield and some agronomic characteristics of popcorn (Zea mays everta Sturt.). Çukurova Üniversitesi Ziraat Fakültesi Dergisi, 16(2), 83-92.

Öner, F., ve Aykutlu, H.M. (2017). Mısır (Zea mays L. indendata) ve soya (Glycine max. L Merr) karışık ekim yöntemlerinin bazı agronomik özelliklere etkileri. Uluslararası Tarım ve Yaban Hayatı Bilimleri Dergisi, 3(2), 100-107.

Özcan, L., ve Özdemir, S. (1996). Ekim sıklığının fasulyede verim ve verimle ilgili karakterlere etkisi. Ege Tarımsal Araştırma Enstitüsü Dergisi, 6(1),17-24.

Pekşen, E. (1998). Mısır ve bodur fasulyenin karışık ekiminde en uygun ekim sekli, düzenlemesi ve zamanının belirlenmesi üzerine bir araştırma. Ondokuz Mayıs Üniversitesi Fen Bilimleri Enstitüsü Tarla Bitkileri Ana Bilim Dalı, Doktora Tezi, Samsun.

Pekşen, E., Gülümser, A., ve Bozoğlu, H. (1999). Karışık ekim sistemlerinin verimliliğini etkileyen bazı agronomik faktörler. Ondokuz Mayıs Üniversitesi Ziraat Fakültesi Dergisi, 14(3), 204-218.

Rao, M.R., ve Willey, R.W. (1983). Effects of pigeonpea plant populations and row arrangament in sorghum / pigeonpea intercropping. Field Crops Research, 7, 203-212.

Roberts, E.H., ve Summerfield, R.J. (1987). Measurement and prediction of flowering in annual crops. In: Atherton, J.G. (Ed.), Manipulation of Flowering. Butterworths (pp. 17-50), London.

Saruhan, V., ve Şireli, H.D. (2005). Mısır bitkisinde (Zea mays L.) farklı azot dozları ve bitki sıklığının koçan, sap ve yaprak verimlerine etkisi üzerine bir araştırma. Harran Üniversitesi Ziraat Fakültesi Dergisi, 9(2),45-
53.

Sönmez, K., ve Kınacı, E. (2014). İç Anadolu koşullarında buğday ve kanolayı takiben yetiştirilen at dişi mısır çeşitlerinin verim ve verim unsurlarının belirlenmesi. Türk Tarım ve Doğa Bilimleri Dergisi, 1(4), 501-508.

Sun, D.L., Yan, X.L., Wang, F.B., Xu, X., ve Lu, R.C. (2013). Mumsu unlu mısırın fizikokimyasal özelliklerinin kontrollü şartlar altında dane doldurma dönemi boyunca yüksek sıcaklığın etkilerinin belirlenmesi. Carbohydrate polymers. Agronomy Journal, 98(1), 302-310.

Tansı, V. (1987). Çukurova bölgesinde mısır ve soyanın ikinci ürün olarak değişik ekim sistemlerinde birlikte yetiştirilmesinin tane ve hasıl yem verimine etkisi üzerinde araştırmalar. Çukurova Üniversitesi Fen Bilimleri Enstitüsü Tarla Bitkileri Anabilim Dalı, Doktora Tezi, Adana.

Tekkanat, A., ve Soylu, S. (2005). Cin mısırı çeşitlerinin tane verimi ve önemli kalite özelliklerinin belirlenmesi. Süleyman Demirel Üniversitesi Ziraat Fakültesi Dergisi, 19(37), 51-60.

Tiryaki, M. K. (2001). Birlikte ekim sistemlerindeki mısır (Zea mays L.) ve fasulyede (Phaseolus vulgaris L.) verim ve diğer agronomik özelliklerin belirlenmesi. Süleyman Demirel Üniversitesi Fen Bilimleri Enstitüsü Tarla Bitkileri Ana Bilim Dalı, Yüksek Lisans Tezi, Isparta.

Tiryaki, M.K., Akman, Z., ve Kara, B. (2004). Mısır ve fasulye karışık ekim sisteminde verim ve bazı agronomik özelliklerin belirlenmesi. Tarım Bilimleri Dergisi, 10(1), 85-92.

Toğay, N., Toğay, Y., Erman, M., ve Yıldırım, B. (2006). Kışlık iki bezelye hattı (Pisum sativum ssp. arvense I.)'nda farklı bitki sıklıklarının bazı tarımsal özellikler üzerine etkisi. Yüzüncü Yıl Üniversitesi Ziraat Fakültesi Tarım Bilimleri Dergisi, 16(2), 97-103

Tsubo, M.S., Walker, S., ve Ogindo,H.O. (2005). A Simulation model of cereals- legume intercropping system for semi-arid regions. Field Crops Research, 93, 23-33.

Turgut, I., Doğan, R., ve Yürür, N. (1997). Bursa koşullarında yetiştirilen bazı atdişi hibrit mısır (Zea mays indentata Sturt.) çeşitlerinde bitki sıklığının verim ve verim ögelerine etkisi. Türkiye II. Tarla Bitkileri Kongresi, 2225 Eylül 1997, 143 - 147, Samsun.

Turgut, i. (2000). Bursa koşullarında yetiştirilen şeker mısırında (Zea mays saccharata Sturt.) bitki sıklığının ve azot dozlarının taze koçan verimi ile verim öğeleri üzerine etkisi. Turkish Journal of Agriculture and Forestry, 24, 341-347.

Yılmaz, M.F. (2005). Kahramanmaraş koşullarında II. ürün mısır bitkisinde farklı sıra üzeri mesafeler ve azot dozlarının verim ve verim unsurları ile tohum kalitesine etkisi. Kahramanmaraş Sütçü İmam Üniversitesi Fen Bilimleri Enstitüsü Tarla Bitkileri Ana Bilim Dalı, Yüksek Lisans Tezi, Kahramanmaraş. 